POST PRINT VERSION OF: Ellis, T. (2019). Using Action Research to Improve Race Relations in Prisons. In Oxford Research Encyclopedia of Criminology and Criminal Justice, ed. Henry Pontell. New York and Oxford: Oxford University Press. doi:10.1093/acrefore/9780190264079.013.300

\title{
Using Action Research to Improve Race Relations in Prisons
}

\author{
Tom Ellis Institute of Criminal Justice Studies, University of Portsmouth, UK
}

\section{Summary}

Tackling racism in prisons has a relatively long policy, practice, and research history in England and Wales. However, clear evidence of success in reducing racism in prisons has been, and still is, difficult to find. This chapter is based on a unique study that was carried out either side of the new millennium (late 1999 to mid-2001), but no equivalent exercise has been repeated since. Due to a unique set of circumstances at the time the study was carried out, it became possible to employ an action research approach that required policymakers, practitioners, volunteers, and researchers to agree on: an emergent research design; implementation; intervention; and measurement. There are many forms of action research, but this study could best be defined as a "utilization-focused evaluation, which is particularly applicable to the criminal justice environment. This approach also included elements of participatory action research." The emphasis here is to show how the action research approach can be both more systematic and more flexible than traditional social science approaches. This applies to both epistemological and research methods considerations, because, by combining theory and action, action research can provide a more viable way of ensuring that policy works in practice, and is sensitive to unique institutional exigencies. Throughout, discussion is contextualised using policy, research and methodology texts from the period when the research was commissioned, but given an overall methodological context by referencing more recent methodology text books.

The article first outlines the context in which the action research study was commissioned, before providing a summary of the international research findings on race relations in prisons, from which key concepts for the project were initially operationalized. The chapter then explains how the specific participatory action research approach was selected as the most appropriate design, the extent to which the approach was successful, and why. The article ends with a discussion of the implications of findings and conclusions from this study for current policy and methodological approaches.

\section{Keywords}

race relations, reducing racism in prisons, utilization-focused evaluation, participatory action research, management buy-in 
POST PRINT VERSION OF: Ellis, T. (2019). Using Action Research to Improve Race Relations in Prisons. In Oxford Research Encyclopedia of Criminology and Criminal Justice, ed. Henry Pontell. New York and Oxford: Oxford University Press. doi:10.1093/acrefore/9780190264079.013.300

\section{Summary of the Race Relations Context in British Prisons at the Turn of the Millennium}

This article is based on a unique study that was carried out in prisons in the northwest of England on either side of the new millennium (late 1999 to mid-2001), a basic summary of which was published in a government report (Ellis, Tedstone, \& Curry, 2004). That report focused only on the positive findings and says little about the unique application of action research (AR) and evaluation methods within prisons. This article therefore focuses on the research, policy, and practice context at the time when the project was commissioned but also references more recent methodology text books and provides a "Further Reading" section for those who wish to pursue an AR approach.

In terms of the specific use of AR, as far as we can ascertain, the study around which this article is based is the only one of its type anywhere in the world. As such, it offers a different policy, practice, and research path than those generally employed to study, or rarer still, improve "race relations" in prisons. The focus here is on AR, and up-to-date sources are referred to throughout. It is beyond the scope of this article to also update developments in race relations in England and Wales prisons, but examples are provided toward the end of this article, which, unfortunately, exemplify how subsequent coverage of race and prisons in England and Wales appears to have fallen back on restating the problem.

At the turn of the millennium, problems with racism in U.K. prisons were a major policy issue and had been raised in a number of prison inspections (e.g., Brixton, Wormwood Scrubs, Wandsworth, Winson Green, Parc, Feltham Young Offender Institution) and related press articles (see, e.g., Walsh, 2001). Prison pressure/volunteer groups had also coincidentally increased their calls for change in this area. In all, there were four major themes, or pressures, which combined to generate this research project: statistical evidence and trends data, the need to revise policy and make it effective in practice, pressure from Black and Asian minority ethnic (BAME)1 prisoner support groups for evidence of action in practice, and research evidence from previous conventional "snapshot" studies on race and prisons. However, before discussing how AR was applied to this area of study, it is first important to establish the key components of AR.

\section{What Is Action Research?}

AR projects must have three key elements: research, action, and participation (Greenwood \& Levin, 1998 , p. 6). AR's purpose is to generate knowledge that is expressly for social change. This requires analysis and a systematic approach, but it must also contribute to social change by facilitating the ability of the involved community and/or organization to better control their own destinies and improve their future capacity to do so (Greenwood \& Levin, 1998, p. 6).

At a fundamental level, AR dates back to Aristotle's concept of phronesis: practical reasoning in action and reflections by local participants on their actions (Greenwood \& Levin, 1998, p. 111). In 
POST PRINT VERSION OF: Ellis, T. (2019). Using Action Research to Improve Race Relations in Prisons. In Oxford Research Encyclopedia of Criminology and Criminal Justice, ed. Henry Pontell. New York and Oxford: Oxford University Press. doi:10.1093/acrefore/9780190264079.013.300

fact, the AR approach to "doing science" has a long though, according to Greenwood and Levin (1998, p. 72), largely ignored tradition. The research approach grew after World War II within a liberationist perspective and with overlapping but philosophically diverse influences (e.g. "liberal humanism, pragmatism, phenomenology, critical theory, systemic thinking and social construction"(Reason \& Bradbury, 2008, p. 3). It is more commonly in use in organizational development, teaching, health promotion and nursing, community development across the world (Reason \& Bradbury, 2008, p. 3), human resources, economics, social psychology, (some) public policy, finance, and marketing (Cameron, 2009, p. 143). It is less well-linked to mainstream academic research (Reason \& Bradbury, 2008, p. 3) and is rare in criminology and criminal justice, despite the need for effective organizational and policy-based initiatives in these fields.

Thus when planning for this study AR was not a mainstream approach in criminological settings. The main influence on the initial AR approach was taken from Greenwood, Whyte, and Harkavy's (1993) "Participatory Action Research as a Process and as a Goal," and, as the project progressed, Greenwood and Levin's (1998) Introduction to Action Research became the main guide. The latter has, therefore, been used as the basis for the AR approach in this article, but other sources, often published much later, are referenced to supplement this. All of the key AR texts come from fields other than criminology and/or race/diversity, emphasizing the cross-disciplinary requirements of $A R$ (Greenwood \& Levin, 1998, p. 8) and its underutilization in criminology and criminal justice.

No student of research methods will be surprised that there is no single definition or approach to AR. Here, it is therefore important to outline the key features common to most AR studies, referencing key texts, which themselves provide a multitude of further sources and resources, that can be used to refine approaches to different problems in different research arenas. AR is also strongly aligned with multi-methods and sequential design (see Cameron, 2009). There is also a commonality "between evaluation research and action research" (Clarke, 1999 p. 27), particularly utilizationfocused evaluations (UFE; see Ellis, Jenkins, \& Smith, 2015, pp. 5-7; Patton, 1997). There is not room here to cover all of these topics, but these are drawn into the later discussion of the specific application of AR to the race in prisons project, which is the focus of this study.

The main singularity of AR is its rejection of the paradigm wars in more "traditional social science" epistemology. At the time of the study, the AR approach was just coming into focus as a result of the intensified debate in the 1980s over the need to move on from a purist division, essentially between qualitative and quantitative paradigms (Cameron, 2009). There is not the space here to cover this vast topic, which Buchanan and Bryman (2007) have referred to as "paradigm soup" ( p. 486), but the growing epistemological eclecticism of the period in which the study took place resulted in one of the earliest criminological applications of the AR approach, requiring "fresh approaches to conceptualization, analysis, and theory building (Buchanan \& Bryman, 2007, p. 486). The test of any theory in AR is, therefore, its ability, in local, concrete circumstances, to resolve real-life problems. This works against conventional ideas of generalizability, transferability and even validity. In AR, the credibility-validity of knowledge is measured instead by workability, that is, whether actions taken 
POST PRINT VERSION OF: Ellis, T. (2019). Using Action Research to Improve Race Relations in Prisons. In Oxford Research Encyclopedia of Criminology and Criminal Justice, ed. Henry Pontell. New York and Oxford: Oxford University Press. doi:10.1093/acrefore/9780190264079.013.300

within it solve jointly identified problems and increase participants' control over their own situations as a result (Greenwood \& Levin, 1998, pp. 75-76).

AR is, therefore, difficult to place within mainstream epistemologies and ontologies and is an approach that is firmly located in the pragmatist philosophical tradition. It is based on the premise that thought and action cannot be separated (Greenwood \& Levin, 1998, p. 6) and that "objectivity" is neither possible not desirable in social science. Indeed, Greenwood and Levin "strongly reject the notion that AR is a particular theory or a specific set of methods" (p. 152). This also prevents research from being separated into pure/applied or qualitative/quantitative categories (Greenwood \& Levin, 1998, pp. 6-7). Most AR researchers would, instead, argue against a traditional social science approach that forces researchers to apply false a priori limits on the research methods or "techniques" they employ. For AR, the methods used should be determined by the research question, not a rigid epistemological position on what is scientific and what is not, and the AR process must also be democratic (all participants accept and understand the approach; Greenwood \& Levin, 1998, p. 7). Greenwood and Levin therefore define scientific research as "investigative activity capable of discovering that the world is not organized as our preconceptions lead us to expect and suggesting alternatives ways of understanding it" (p. 69), not as the (logical) positivist stance of seeing the world as objectively given, requiring only the epistemological effort to apply objective methods to uncover the truth (p. 68). As a result, they appear to favor hermeneutics, whose ontology is subjective, so that the epistemological task is to interpret the subjective world well (p. 68) and fall firmly within a qualitative/interpretivist epistemology.

However, this focus was more of reaction to the dominance of positivism in social science at that time. Greenwood and Levin (1998) agree that not all positivist endeavors are "nonsense" (p. 69) but rather that they do not fully reflect the world that scientists live in, with often "imperfect instruments and finite energies and budgets." (p.69) Perhaps a better way of conceptualizing AR is to see it as more akin to a general systems theory approach, in that it focuses on the interaction between open and closed systems, rather than on individuals as units of analysis (Greenwood \& Levin, 1998, p. 70). Elsewhere, Greenwood and Levin (1998, pp. 187-202) also argue that AR overlaps with action science for organizational learning (see Argyris, Putnam, \& McClain Smith, $\underline{1985}$ ) and with participatory evaluation (pp. 235-241), particularly Guba and Lincoln's (1989) constructivist Fourth Generation Evaluation as a way of developing a "postpositivistic," rather than simply an antipositivistic, approach.

Both AR and general systems theory are therefore based on a view that "individuals operate within systems that create process environments that affect the outcomes of behavior in complex ways ... systems and system processes, bumping into each other in a variety of ways" (Greenwood \& Levin, 1998, p. 70) to form a total situation. That situation, though, is also dynamic, and therefore historical, so that the traditional positivist view of hard outcomes is replaced by one of processes in continual motion (Greenwood \& Levin, 1998, p. 71). 
POST PRINT VERSION OF: Ellis, T. (2019). Using Action Research to Improve Race Relations in Prisons. In Oxford Research Encyclopedia of Criminology and Criminal Justice, ed. Henry Pontell. New York and Oxford: Oxford University Press. doi:10.1093/acrefore/9780190264079.013.300

My understanding of Greenwood and Levin's (1998) approach, then, which they summarized neatly in their map of $A R$ (p. 90), suggests that AR was positioned between realism/positivism and relativism/hermeneutics/interpretivism but also between community and authority. In rejecting the existing, extreme epistemological positions of the time, AR processes were aimed instead at creating an arena in which the forces of authority and community, realism and relativism, meet in communicative situations that are structured to open up all positions for scrutiny as well as for positive contributions ... and aims to keep the conversation going. (Greenwood \& Levin, 1998, pp. 90-91). AR thus becomes the process of bridging/combining local and scientific knowledge to create new knowledge and understanding in both arenas (Greenwood \& Levin, 1998, p. 111).

Also key to the race and prisons topic was the AR requirement that social scientific knowledge should not be developed as an esoteric and elitist project to apply science to passive subjects but should involve all participants and their perspectives and understanding, to support democratic and egalitarian approaches. Unsurprisingly, these issues were not discussed in agreeing on the methodology for the prison project, but, within the context of the study, "bringing together ... conflicting experiences ... by working democratically to ameliorate intolerable situations" (Greenwood \& Levin, 1998, p. 74) might describe the position of lobby groups, volunteers, and policymakers who were all trying to improve the lives of BAME prisoners. The key pragmatist element here is the permanently provisional nature of "solutions" that are "only the best possible at that moment with the materials at hand" (Greenwood \& Levin, 1998, p. 74). Ideally, in AR, there should therefore be a continuous cycle of results, further action, and improvement (see Figure 1).

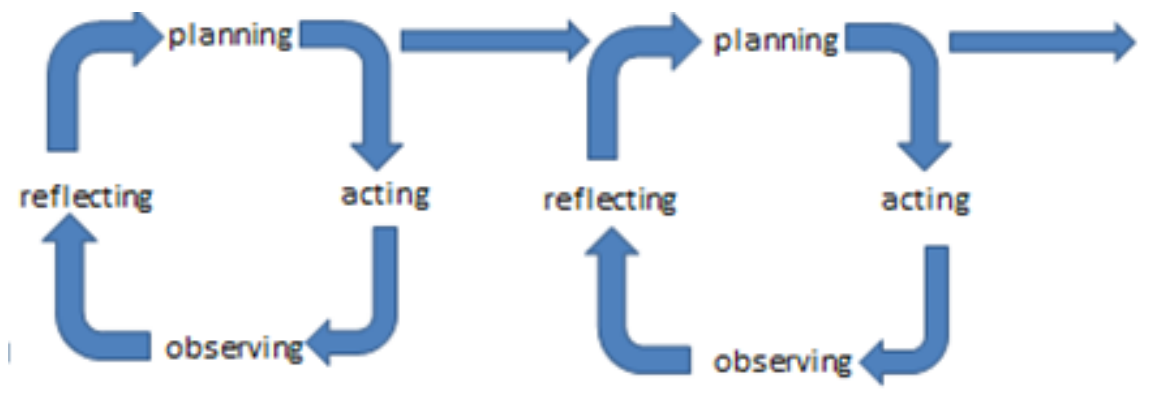

Figure 1: Sequences of action-reflection cycles - adapted from McNiff (2002: 41)

However, for our project, all parties were aware that achieving a single and successful action cycle would be a major and innovative step forward. Beyond this, at that time, AR requirements for a decentralized, context-bound inquiry into local problem and specific sets of policies to improve race relations in different establishments seemed antithetical to the general, national criminal justice policymaking process. Indeed, Greenwood and Levin (1998) would recognize that AR's express aim of "disrupting power relationships for the purpose of democratizing society" (pp. 88-89) was going to be a delicate sell to a government department. However, within these real-world limitations, 
POST PRINT VERSION OF: Ellis, T. (2019). Using Action Research to Improve Race Relations in Prisons. In Oxford Research Encyclopedia of Criminology and Criminal Justice, ed. Henry Pontell. New York and Oxford: Oxford University Press. doi:10.1093/acrefore/9780190264079.013.300

there was a recognition by all parties that practical problems are not necessarily simple ones (Greenwood \& Levin, 1998, pp. 76-77), and so we managed to establish that there was an opportunity to combine all parties' perspectives on a specific (AR) problem: how to improve race relations in prisons.

Focusing on one cycle at this point was also a way of avoiding potential misunderstandings about the AR approach by participants. At times, it can seem that outcomes are rejected in AR in favor of a continual process (Greenwood \& Levin, 1998, p. 74) while at others "the inquiry process is argued as an integration of action and reflection and the test of the tangible outcome as workability" (p. 82; i.e., resolving the initial problem [p. 77]). This could seem inconsistent if viewed from traditional epistemological standpoints. Indeed, Greenwood and Levin note that "conventional social scientists ... see $[A R]$. . . as unsystematic, atheoretical story telling" (p. 75). AR practitioners would argue, instead, that conventional social scientists promote knowledge that is isolated and impractical because it lacks the action, reflection, and commitment necessary to solve real-life problems. In this AR approach, truth is not a positivist universal "thing" to be finally revealed but is "rather an aim of an endless process of collaborative social inquiry"(Greenwood \& Levin, 1998, p. 87). In this case, it is easier to view the AR approach itself as the key or "process" and outcomes as always interim, or provisional, and subordinate to the role in the continuing AR process - a way of "keeping the conversation" going (Greenwood \& Levin, 1998, p. 87) instead of discovering a silver bullet that will tarnish quickly.

Greenwood and Levin (1998) called this "pragmatic action research," which required a cogenerative "framework for thinking through how to choose appropriate methods and action" (p. 115). Rather than being viewed as a type of qualitative (only) research, "It is fully and necessarily compatible with the deployment of a wide variety of research techniques and agendas" (pp. 114-115).

For this project, we felt that the AR approach most represented what we were attempting to achieve, but readers can decide for themselves, based on further reading, whether it is better described as participatory evaluation or even action science. All of these overlap, but as Greenwood and Levin (1998) note, there is no single, correct recipe. The approach must consider the particular problem, location, parties involved, and so on. However, all AR requires (democratic) mutualism (i.e., the reconciliation of insider and outsider position; Greenwood \& Levin, 1998, p. 77). It requires trained social researchers (outsiders) who partly act as facilitators and teachers, but they are only one type of participant in the research process, rather than external and objective experts. It also, therefore, requires collaboration with participants in their own situation (insiders) and professionals who take account of the historical and political contexts of the participants' lives (Greenwood \& Levein, 1998, p. 77). The result is cogeneration of approach and knowledge. There are many different versions of insider/outsider positionality, for instance, Herr and Anderson (2005, p. 31) outline six different approaches, none of which was quite appropriate to describe the approach taken in this project. We were closest to Herr and Anderson's "outsiders in collaboration with insiders," but there were multiple agencies involved and the relationships changed over time. These positions will affect the 
POST PRINT VERSION OF: Ellis, T. (2019). Using Action Research to Improve Race Relations in Prisons. In Oxford Research Encyclopedia of Criminology and Criminal Justice, ed. Henry Pontell. New York and Oxford: Oxford University Press. doi:10.1093/acrefore/9780190264079.013.300

methodology and even validity of the study, but trying to "fit" into one of them will cause more problems than deriving the best approach based on the context and the problem addressed (Greenwood \& Levin, 1998, pp. 152-153).

Overall, the pragmatic or neopragmatic philosophical position established for AR here is consistent with the three key elements of (pragmatic) AR (Greenwood \& Levin, 1998, pp. 152-153):

- Constructing arenas for dialogue-where participants (including researchers) can engage in a dialogical relationship that allows mutual learning.

- Cogenerative research-where the research process emerges from joint experiences and mutual reflections about them.

- Use of multiple methods - a rejection of AR as a particular theory or methodology; instead, processes are mutually decided on as appropriate and requisite skills are gained to deploy them.

However, as Greenwood and Levin (1998) note, "Because our approach is purposely fitted to local conditions, we cannot describe it in narrow terms ... in a single chapter" (p. 153). The discussion thus far provides enough understanding of the key elements of an AR approach; readers can pursue further reading as desired. The rest of the article is therefore dedicated to outlining the project on improving race relations in prisons and drawing on the key AR elements as they were applied.

\section{The Millennial "Racial" or "Ethnic" Statistical Profile of Prisons in England and Wales}

In preparing for the research, Prison Statistics for England and Wales (PSEW, 1997, pp. 104, 107) clearly showed that people from ethnic minority groups were over represented in the prison population compared to what would be expected from their representation in the population of England and Wales as a whole. Those from ethnic minority groups made up $18 \%$ of the male prison population and $25 \%$ of the female prison population (PSEW, 1998). This represented the following incarceration rates per 100,000 population for the following groupings: White, 176; Black, 1,249; South Asian 150 (see Chapter 5 of PSEW [1997], fig 9.7, paras 9.19, 9.20). In short, this was three times the rate expected from their distribution in the general working population of England and Wales (PSEW, 1998). Over a long period of time, while the White prison population had risen by $31 \%$, the Black prison population had grown by $101 \%$ and the equivalent South Asian population by $80 \%$ (see Bowling \& Phillips, 2002, pp. 192-199). Tonry (1995) had already identified an analogous situation in the United States, where Black prisoners would be expected to form $40 \%$ of the prison population based on proportionate overall population figures but in fact comprised $50 \%$.

While the focus here is on improving race relations within prisons, it is important to bear in mind the limited explanatory power of these figures. Most textbooks, (see, e.g., Phillips \& Bowling, 2002) outline how prison reception is the final stage of the criminal justice process and note that it is 
POST PRINT VERSION OF: Ellis, T. (2019). Using Action Research to Improve Race Relations in Prisons. In Oxford Research Encyclopedia of Criminology and Criminal Justice, ed. Henry Pontell. New York and Oxford: Oxford University Press. doi:10.1093/acrefore/9780190264079.013.300

important to consider other criminological factors that are differently impacted by race/BAME, such as the type of offense whether the offense is reported to/recorded by the police, whether the offense is proceeded against, the plea, the type of sentencing court, the offender's age, and previous convictions. In addition, broader social factors, such as class, education, employment status, and social deprivation, vary by race/BAME.

However, the starting point for our research was neatly summarized, within the literature, reviewed by Komiya (1995):

prison administration has no control over the numbers of ethnic minority prisoners even though it feels the courts are often the source of racial injustice. It must therefore pursue racial justice with its own resources given the racially-disproportionate prison population. (pp. 269-270)

\section{Policy Initiatives}

As Morgan (1997) noted, "The Prison Service has for many years monitored more closely the ethnic composition of the population with which it deals than possibly any other public service" (p. 1156). By the time this AR study was commissioned, there had been a Prison Service race relations policy for 18 years. This policy was revised several times (see Jackson, 1997), and in the mid-1990s the Prison Service's approach to race relations was scrutinized by the Oxford Centre for Criminological Research. The reports on this scrutiny (Burnett \& Farrell, 1994; Criminal Justice Consultative Council, 1994) were followed by pilot studies to implement new antidiscrimination initiatives. What were regarded as the best practices from the pilots were used, in turn, to inform the Prison Service Order on Race Relations, which was published in May 1997 and was implemented throughout the prison estate. The order was well received by the National Association for the Care and Resettlement of Offenders (NACRO), the Commission for Racial Equality (CRE), and the Prison Reform Trust (PRT). The PRT went so far as to say that while the Prison Service's Policies went further than most other organisations, turning (Jackson, 1997) policy into practice would not be easy. is not always easy."

Race relations policy in prisons at this time was derived from Prison Service Order 2800:

The Prison Service is committed to racial equality. Improper discrimination on the basis of colour, race, nationality, ethnic or national origins, or religion is unacceptable, as is any racially abusive or insulting language or behaviour on the part of any member of staff, prisoner or visitor, and neither will be tolerated. (HM Prison Service, 2002)

This also tied in well with the Race Relations (Amendment) 2000 Act. But what were the concrete elements to this policy?

First, in order to comply with the Prison Service's policy statement, every prison has a race relations liaison officer (RRLO). The RRLO role, outlined in Prison Service Instruction 78/2000, was to be a point of contact for prisoners to discuss any race-related issues, intervene in disputes of a racial 
POST PRINT VERSION OF: Ellis, T. (2019). Using Action Research to Improve Race Relations in Prisons. In Oxford Research Encyclopedia of Criminology and Criminal Justice, ed. Henry Pontell. New York and Oxford: Oxford University Press. doi:10.1093/acrefore/9780190264079.013.300

nature, and provide information (e.g., national and local policies) to staff and prisoners. Each prison also has a race relations management team (RRMT) to develop strategies to combat racial issues.

The key policy strategies implemented by the Prison Service were RESPOND and RESPECT. RESPOND focused primarily on prison staff equality (e.g., making the ethnic profile more representative of U.K. communities). Only one of RESPOND'S five key objectives was directly relevant to prisoners: "ensuring equal opportunities for ethnic minority prisoners," although there was a general inclusion under a second objective of confronting racial harassment and discrimination.

As Clements (2002) later noted, the main focus had been on the diversity agenda for prison staff, rather than on prisoners' experiences. It seemed easier to focus on staff and evidencing changes in their conditions rather than on prisoners. Most effort was put into ensuring fairness in recruitment, appraisal, promotion, and selection by developing RESPECT (a supportive network for BAME prison staff). The general objective of confronting racial harassment and discrimination resulted in a new complaints system, but the more specific prisoner-focused objective also resulted in a number of gains for prisoners, as summarized in Table 1.

Table 1: Specific prisoner-focused changes under the RESPOND Prison Service policy initiative

- Establishment of Director General's advisory group on race

- New definition of racist incidents accepted.

- Introduction of four new racially aggregated offences in prisoner rules:

- Racially aggravated assault

- Racially aggravated damage or property destruction

- Threatening, abusive or insulting racist words/behaviour
- More allocation of time for RRLO role.

- Racial equality training for all chairs of RRMT.

- Action research ${ }^{1}$

- Template to enable review of race relations.

- Muslim advisor appointed.

- Piloting diversity training for prisoners.

This relative staff/prisoner balance was also reflected in the review that I carried out on the domestic and international literature on prisons. This relative lack of focus on improving BAME prisoners' experiences was one of the contributory factors in the escalating pressure from BAME lobby/volunteer groups.

\footnotetext{
${ }^{1}$ Included due to the influence of our early discussions - see below 9
} 
POST PRINT VERSION OF: Ellis, T. (2019). Using Action Research to Improve Race Relations in Prisons. In Oxford Research Encyclopedia of Criminology and Criminal Justice, ed. Henry Pontell. New York and Oxford: Oxford University Press. doi:10.1093/acrefore/9780190264079.013.300

\section{Impact of the National Body of Black Prisoner Support Groups}

Despite the long prisons' race policy history in U.K. prisons, by 1998, the National Body of Black Prisoner Support Groups (NBBPSG) was referring to a series of negative press articles, often provoked by publication of official inspection reports, to lobby for concrete improvements in the treatment of BAME prisoners.2 The two key Home Office/Prison Service commissioned research studies, Genders and Player (1989) and Burnett and Farrell (1994 [reviewed later]), had resulted only in limited policy changes, mostly focused on a checklist to ensure an antiracist policy was in place in each prison. Their impact on practice was therefore unclear to the NBBPSG.

The repeated publicity resulted in the Prison Service's recognition that the NBBPSG's concerns were legitimate and pressing. It established the Prison Service Race Relations Group (PSRRG) in 1998 to address the problem of turning prison race relations policy into practice. In his speech to the first national conference of the NBBPSG on May 7, 1998, Richard Tilt, Prison Service director-general at the time, noted

The size and composition of the prison population are not within the control of the Prison Service. . . However, it is central to the function of the Prison Service that we treat those sentenced to our custody with humanity and with fairness. [which] means guarding against discrimination in all its forms, and dealing with it when it does occur. (see Narey, 2002)

The first PSRRG meeting was on July 24, 1998, and was an informal "brainstorming" session between Black and Asian prisoner support groups, the Home Office's Prisoner Administration Group, the Home Office's Research Development and Statistics Directorate (RDS), the Prisons Inspectorate, and academic researchers. Our situation in the PSRRG was a relatively complex one, involving a number of groups and gradations of insider/outsider positions. Within an AR approach (see Greenwood \& Levin, 1998 , p. 86), this session was effectively devised as an initial cogenerative way of creating a space for collective reflection between a number of parties with a mutually agreed-on problem focus (Greenwood \& Levin, 1998, p. 117), the seemingly intractable problem with racism in prisons, but with vastly differing positions and views on how to exploit resources to tackle it (action) and what would constitute effective action (analyses). The NBBPSG was very keen on action with not much thought about how to measure its success, while policymakers were unsure how successful action could be measured.

At this time, I was effectively an "outsider" researcher in the RDS for the Home Office in England and Wales and so was both fully involved in the PSRRG negotiations and also expected to suggest and coordinate an appropriate research strategy (PSEW, 1998). Reflecting on this meeting, it was clear that my exploration of AR methods was instrumental in my role within the meeting, although relatively inchoate at that point.

It was clear that the NBBPSG wanted the most effort focused on demonstrable action to improve race relations in prisons. It was also effective in developing a consensus within the PSRRG that there 
POST PRINT VERSION OF: Ellis, T. (2019). Using Action Research to Improve Race Relations in Prisons. In Oxford Research Encyclopedia of Criminology and Criminal Justice, ed. Henry Pontell. New York and Oxford: Oxford University Press. doi:10.1093/acrefore/9780190264079.013.300

was already enough "traditional-style" research evidence to suggest that both direct and indirect racism existed in England and Wales prisons and that it would be unhelpful to simply fund more of the same type of research, which was referred to as "false action" and "lip service." It seemed that the NBBPSG, along with the general public, had lost faith in academic social science, finding it "unintelligible, self-serving, and, where ... understandable, either banal, or wrong" (Greenwood \& Levin, 1998, p. 125).

However, on a broader level, there was agreement among all parties that there was a need for an evidence-based approach to overhaul prisons race relations policy so that it was possible (a) to measure the extent of discrimination against BAME prisoners and (b) to identify effective processes to reduce such discrimination (Ellis et al., 2004).

As Dantzker and Hunter (2012) note, "it is common for researchers to publish their results without ever explaining how their concepts were operationalized" (p. 48). The nature of an AR project, and the parties involved, did make this a key task. This required agreement within the PSRRG on the key findings from existing research and being as explicit as possible in showing how we made our concepts observable and concrete to offer readers a clearer picture of how we "conceptualized" this topic (Dantzker \& Hunter, 2012, p. 47). This also means that the account of our AR project necessarily required the "telling of its story" (Greenwood \& Levin, 1998, p. 81), so that it was clear how all parties were included (i.e., anyone who had a stake or vested interest in evaluation findings; see Patton, 1986, p. 43).

Importantly, then, in many AR projects, a lot of effort must be put into gathering everyone in a large room and establishing a democratic dialogue to work out plans for a new project (Greenwood \& Levin, 1998, p. 117). However, for this project, these typical first AR stages to clarify the initial research question and to construct meanings around the required social change had largely been done for us by the years of failure to translate policies into action, plus the associated pressure from negative media coverage. This was not where the research effort was required. Indeed, the PSRRG meetings were a remarkably successful arena to agree on the dimensions of racism identified and the level of detail required. The PSRRG therefore agreed on an AR approach, but it was also agreed that there was an initial research requirement to review the existing (English-language) research literature to identify and summarize key findings, any effective practices, and ways to operationalize these findings into a research proposal.

This meant that the next AR stages of reshaping of the question, as more learning took place, were effectively postponed until the focused literature review results could be presented. This included any remaining conflict around the type of action and/or research methods required. The first step for me was, then, to gain insight from existing research and from the discussions between the (partially conflicting) participants to suggest a research design that would satisfy all involved parties and be most likely to deliver successful outcomes that would be agreed on as demonstrating 
POST PRINT VERSION OF: Ellis, T. (2019). Using Action Research to Improve Race Relations in Prisons. In Oxford Research Encyclopedia of Criminology and Criminal Justice, ed. Henry Pontell. New York and Oxford: Oxford University Press. doi:10.1093/acrefore/9780190264079.013.300

workability (Greenwood \& Levin, 1998, pp. 114-115). Before that can be discussed, however, it is important to outline the key findings from the focused literature review.

\section{Previous Research Findings on Race and Prisons: A Research Literature Review}

At the time there was very little academic literature on identifying and reducing race-related problems in prisons. What there was mostly related to the United States and the United Kingdom. Most of the academic focus was understandably on wider, precustody issues (see Tonry \& Melewski, $\underline{2008})$. For instance, Fox (1982) employed Etzioni's (1975) framework of compliance relationships in complex organizations to survey 55 prison officials, 900 prison guards, and about 750 prisoners. His main conclusion was that long-term effects of structural racism in free society had created racial conflict inside U.S. prisons. His recommendation was for prison guards to replace racially divisive tactics with more positive approaches to reduce racial tension. However, a non-AR approach meant that there were no practical or detailed outlines on how to achieve this.

This was the starting point for an extensive literature search specifically on "race and prions" in social science citations indexes as well as through the Federal Bureau of Prisons, U.S. National Institute of Corrections, U.S. National Institute of Justice, U.S. National Criminal Justice Reference Service, previous U.K. government research, and European research through HEUNI.3 However, very little was found on practical race relations initiatives within prisons. Most American (and Canadian) policy and research related to the implementation and monitoring of affirmative action (Hochstedler, 1982; Maine Department of Corrections, 1982, 1987; Moskoff, 1980). The other major focus was on prison staff in relation to employment selection and advancement, perceptions of opportunities, guard culture, and so on (Camp, Steiger, Wright, Saylor, \& Gilman, 1997; Fairchild, 1995; Owen, 1985). Those studies that were most clearly related to outlining and/or improving race relations in prisons are incorporated in the remainder of this article.

In contrast to the narrower "race and prisons" literature, Price and Leibling $(1998$, p. 164) reviewed the body of sociological literature on prison social life. This tended to be older than the race and prisons literature and concentrated on prisoner behavior and prisoner subculture but, in contrast, rather neglected prison staff (see, e.g., Clemmer, 1940; Goffman, 1961; Sykes, 1958). These studies indicated that prison relations can be highly complex as there are points of mutual interest (convergence) and points of opposition (Price \& Liebling, 1998, pp. 162-163). The sociological literature is incorporated in this article where relevant to the focus of the study. Within this, Shapira and Navon (1985) made a key observation that is very pertinent for an AR perspective: the study of the use of informal power by those at the lower level of prison organization has been neglected. Although most evidence shows prisons conform to Goffman's (1961) total institution, there was also evidence of cooperation between basic grade prison staff and inmates to achieve a "negotiated order." Therefore, Shapira and Navon argued that in assessing discrimination in prisons, it is as 
POST PRINT VERSION OF: Ellis, T. (2019). Using Action Research to Improve Race Relations in Prisons. In Oxford Research Encyclopedia of Criminology and Criminal Justice, ed. Henry Pontell. New York and Oxford: Oxford University Press. doi:10.1093/acrefore/9780190264079.013.300

important to assess the informal operation of power norms as it is to assess the formal organizational structure and policy.

It is important, therefore, to look at research that provides evidence of the concrete elements of any informal negotiations between staff and inmates. Genders and Player (1989) were certainly the vanguards in exploring this area in the United Kingdom and built their work on U.S. literature. As a result, they concentrated on three 4 areas where direct and/or indirect discrimination were likely to occur: disciplinary proceedings, wing and cell allocation, and allocation of jobs and training. These are explained in turn next.

\section{Disciplinary Proceedings}

At the time of our study, U.K. prison governors dealt with most breaches of prison discipline according to the Prison Rules (1964) and Young Offender Institution Rules (1988), with only very serious criminal offenses referred to the police. Therefore, prison officers had high levels of discretion in referring offending prisoners for adjudication, as did prison governors for subsequent punishment/s. This allowed for discriminatory practices (conscious or unconscious) at various stages of the disciplinary process. Correspondingly, PSEW (1997) showed that Black prisoners experienced higher adjudication rates and more punishments per offense than White prisoners (Genders \& Player, 1989).

Genders and Player's (1989) approach was built mainly on U.S. and U.K. studies, which varied in size and approach and whose findings were not always consistent. Some (Boyd, 1976; Petersilia, 1983; White, 1980) found no significant difference between the rate of disciplinary reporting for Black and White prisoners. Others showed higher rates for Black compared to White prisoners (Flanagan, 1983; Ramirez, 1983), while Petersilia, Honig, and Hubay (1980) found a higher rate for White compared to Black prisoners.

Caroll (1974) found discretion resulted in significantly higher use of disciplinary procedures against Black compared to White prisoners in U.S. maximum-security prisons (but no difference in subsequent punishments severity). Poole and Regioli's (1980) self-report studies also found Black and White prisoners broke rules with equal frequency, but Black prisoners were more likely to be officially reported. Ramirez's (1983) later U.S. study also found disproportionately more (bad) conduct reports were written on Black than on White inmates. He concluded that racial bias varied according to the amount of discretion afforded the decision-maker and the extent to which the decision-maker is accountable. Only Caroll (1974) recommended action. He argued that prison staff's perception of Black prisoners as more dangerous should be addressed, which would also reduce Black prisoners' perceptions of unfair treatment and hostile responses. Again, there were no practical or detailed outlines on how to achieve this in AR terms.

Genders and Player (1989) found similar results in U.K. research based on monitoring and self-report offending in three prisons. There were no differences in the proportions of Black and White inmates 
POST PRINT VERSION OF: Ellis, T. (2019). Using Action Research to Improve Race Relations in Prisons. In Oxford Research Encyclopedia of Criminology and Criminal Justice, ed. Henry Pontell. New York and Oxford: Oxford University Press. doi:10.1093/acrefore/9780190264079.013.300

involved in serious or violent incidents with other inmates or staff. However, staff intervened in half the incidents involving Black or Asian prisoners but only a quarter involving White inmates. Importantly, adjudication then occurred for all cases of intervention, thereby producing a racial differential.

PSEW (1997) showed a total of 108,200 offenses against prison discipline: a rate of 177 per 100 prisoners. Black male prisoners were recorded as committing around $25 \%$ more proven offenses against prison discipline than White males, while there was little difference between Black and White female prisoners. All other ethnic groups had low adjudication rates (PSEW, 1997). There were twice as many proven violent offenses per person for Black prisoners, but Black prisoners had fewer adjudications for willful damage or escape.

Punishments ran at 298 per 100 prisoners in 1997. Additional days were the most common punishment (121 per 100 prisoners), followed by forfeiture of privileges and stoppage/reduction of earnings (68 per 100 prisoners). Cell confinement was used in over one-third of assaults, which disproportionately affected Black offenders due to higher involvement in violent offenses. Patterns of punishment also varied between types of establishment and for types of offense committed. However, Black prisoners received more punishments per offense than White prisoners even when offense type was controlled for (PSEW, 1997).

For our study, it was clear that variations in adjudication practices and/or perceptions of these needed to be operationalized. Importantly, for our study, as with PSEW, Genders and Player (1989; see also Price \& Liebling, 1998) found all dimensions of discrimination varied between individual establishments and different categories of prisons. The implication for an AR approach was that strategies to improve race relations would therefore have to vary accordingly, as might effective measures to evaluate them. This had to be reflected in any research design.

\section{Prison, Wing, and Cell Allocation}

Genders and Player (1989) also found differential racial allocation of prison accommodation. Fifty percent of prison officers interviewed argued for the need to strictly limit the number/proportion of Black prisoners within individual prisons (only $20 \%$ for Asians) to reduce the likelihood of power struggles. Goffman (1961) argued that there was always a conflict between official policy or "what the institution does" and how this is mediated once staff are faced with "real people work" (p. 75). Cheatwood (1974, p. 179) took this further and argued that prison staff's approach to prisoners in general was always going to appear contradictory over time, and between institutions, due to their strained position between administrative and inmate demands. This echoed Goffman's (1961, pp. 84-86) notion of "role release," where staff and prisoners continually cross each other's subcultural lines, and Ben-David, Slifen, and Cohen's (1996) later argument that prison officer environments offered many irreconcilable demands beyond a simple therapy-custody dichotomy. Price and Liebling (1998) took this further in the United Kingdom and, key to our project, delineated three 
POST PRINT VERSION OF: Ellis, T. (2019). Using Action Research to Improve Race Relations in Prisons. In Oxford Research Encyclopedia of Criminology and Criminal Justice, ed. Henry Pontell. New York and Oxford: Oxford University Press. doi:10.1093/acrefore/9780190264079.013.300

ways in which staff-prisoner relations could corrupt institutional policy so that they might impact on discriminatory behavior.

First, if confidence in prison management was low and staff felt they suffered the same "unreasonable caprice of power" as prisoners, they were more likely to develop friendships and respect for prisoners who yielded power (see Chang \& Zastrow, 1976, p. 109). Second, Price and Liebling (1998, p. 164) found that staff tended to develop reciprocity with prisoners and overlooked certain rule infractions to buy compliance with others. McCorkle and Korn (1962, p. 110) also argued that this helped to buy insurance in times of violent disorder, especially if staff had few formal rewards for prisoners. The third element was by default; that is, underperforming prison officers transferred minor tasks to prisoners through laziness, naivety, or indifference.

In the context of this study, while prison officers had little control over the formal race-blind policy and practice of allocating prisoners to individual prisons, Genders and Player (1989) found evidence that there were two key ways for them to control the overall numbers of Black prisoners: one is by manipulating the prison transfer process between prisons but another, perhaps more significant for racially biased prison staff behavior, is the hidden but considerable officer discretional control of prisoner distribution within prisons (i.e., between wings, landings, and cells). These findings suggested that operationalized measures to reduce staff discrimination would have to include these two factors.

\section{Allocation of Jobs and Training}

Genders and Player (1989) followed Goetting and Howsen's (1983) U.S. national survey of 11,000 prisoners in scrutinizing the differential allocation of prisoner jobs and training. The latter found no significant racial differences in the easily measurable "average number of hours worked" or "proportion who were paid" but pointed to the New York State Special Commission on Attica (1972), which showed discrimination in the type of work assignments and pay rates. Echoing Shapira and Navon (1985), Goetting (1985) also argued that both formal and informal prison practices discriminate against Black prisoners but that discrimination by White guards and inmates was most severe when formality, visibility and accountability were lowest, which then impacted on their access to educational, vocational, recreational, and industrial programs.

Unsurprisingly, Genders and Player (1989) subsequently found clear evidence of U.K. prison officers operating informal policies to exclude Black and Asian prisoners from the most desirable prison jobs (i.e., kitchen, gym, library, and reception orderlies). This was also true to a lesser extent for education and training. While Genders and Player (1985) found BAME prisoners were generally unaware of this discrimination, Burnett and Farrell's (1994) later research showed that BAME prisoners' awareness had increased considerably and had also extended to other areas (e.g., lack of specialist shop products, making phone calls, being searched, and disciplinary processes). The Prisoner's Earnings Act (1996) had also brought a sharper focus to differential treatment, and Smartt and Vagg (1998) added that these more conspicuous differences were clear along ethnic lines. 
POST PRINT VERSION OF: Ellis, T. (2019). Using Action Research to Improve Race Relations in Prisons. In Oxford Research Encyclopedia of Criminology and Criminal Justice, ed. Henry Pontell. New York and Oxford: Oxford University Press. doi:10.1093/acrefore/9780190264079.013.300

Pertinent to the allocation of opportunity, in the period of our study, prison officers' written assessments of prisoners were governed by Prison Department Circular Instruction 56/1983, which focused on ensuring racially discriminatory language was absent. Genders and Player (1989) analyzed 1,255 written records (standard classification forms) and found that this was complied with. However, they also found this did not prevent racial stereotyping in related assessments of personality and training needs (differences in previous training, disciplinary offenses, and age were controlled for). On each dimension, 5 Black prisoners were rated significantly lower than White prisoners, although the reverse was true of Asians. For training assessments, Black prisoners were also assessed as needing more development in work patterns and skills. It seemed clear, then, that measures of differential job/training allocation also needed to be operationalized

\section{Staff-Prisoner Relationships}

Most of the studies in the literature review focused on evaluations of staff-prisoner relationships, with any findings on race issues included as part of these broader investigations. Price and Liebling's (1998) review of staff-prisoner relationships was no exception, but there were some important general issues that were potentially applicable to staff-BAME prisoner interaction. Most studies fell into two main camps (Price \& Liebling, 1998, p. 162):

- Sociological studies from the United States (1960s and 1970s) and Israel (1980s and 1990s) with clear theoretical development but meager quality empirical data.

- Empirical studies from the United Kingdom (1990s) with little attempt to develop a theoretical framework.

Price and Liebling therefore combined the main findings from each to promote more effective research in this area.

An early study by Chang and Zastrow (1976) had investigated inmates and prison officers' views of themselves and each other. They found that prison officers evaluated themselves and others in their role highly but evaluated inmates negatively, while prisoners evaluated both other inmates and prison officers quite negatively. Chang and Zastrow argued that it was important to address these negative evaluations so that prisoners felt accepted, understood, and valued in order to facilitate positive behavioral changes in therapeutic settings. In an analogous study, Ben-David and Silfen (1994) found that staff and (psychiatric) inmates had quite different views on the "preferred qualities of staff-inmate relationships." Staff members thought a combination of authority, informal low key control, support involvement, and inmate autonomy were important. In contrast, inmates preferred to experience staff as "authoritarian patrons with an apparent wish to be controlled by a clear definite set of rules and expectations" (p. 132). James, Bottomley, Leibling, and Clare's (1997, pp. 105-109) study showed a mismatch between relatively poor reported staff-prisoner relations but that staff had significantly higher levels of satisfaction with their work. 
POST PRINT VERSION OF: Ellis, T. (2019). Using Action Research to Improve Race Relations in Prisons. In Oxford Research Encyclopedia of Criminology and Criminal Justice, ed. Henry Pontell. New York and Oxford: Oxford University Press. doi:10.1093/acrefore/9780190264079.013.300

Overall, Price and Liebling (1998, p. 178) were struck by their findings that there was no necessary correlation between how well the prisoners rated the staff and whether there were assaults and other disciplinary troubles. This led them to question whether "close" relations between staff and prisoner were "good" relations. It seemed that prisoners and staff rated a disciplined, safe environment with clear and relatively firm boundaries above respect, honesty, and good communication (Price \& Liebling, 1998, pp. 181-182) and James et al. (1997) argued prisoners did not want to be too close to staff which felt "too much like grassing" (p. 123). This indicated that perceptions of the quality of staff-prisoner relations would need to be operationalized in our study but, as with Genders and Player (1989), it also required an examination of fairness in prisons.

\section{Fairness in Prison}

Again, fairness studies did not focus explicitly on race relations prisons, but they have direct implications for identifying potential and actual discrimination. Ahmad (1996) found that prisoners' concepts of staff fairness and regime fairness varied independently, but staff fairness was the strongest determinant of the perceived overall regime fairness. This strengthens Goffman's (1961) and Cheatwood's (1974) view that changes to regime conditions have little impact on prisoners' assessment of the overall fairness unless there is a minimum level of staff fairness within "real people work." Indeed, Bottoms and Rose's (in Price \& Liebling, 1998) secondary analysis of Ahmad's data found that "fairness" and "staff-prisoner relationships" were virtually indistinguishable from each other, irrespective of other variables considered. It is clear then that frontline staff embodied the regime of a prison so that any exploration of improving race relations in prisons would necessarily have to operationalize BAME prisoners' perceptions of fairness among those that dealt directly with them. A later study by Burnett and Farrell (1994), also commissioned by the Home Office, confirmed Genders and Player's (1989) findings, but added three additional, specific dimensions of potential/actual racism that needed to be operationalized.

Verbal abuse and harassment were the most frequently reported type of direct racism, both between staff and prisoners and between inmates.

Availability of specialist products (see also Jackson, 1997), or the lack of Black hair and skin products, specialist magazines, newspapers, and food, resulted in double the number of complaints from Black prisoners, compared to White, about shop/canteen facilities, despite all prisoners generally supporting provision of specialist products and services (Genders \& Player, 1989).

Reporting and investigating racial incidents showed that less than a quarter of inmates of any ethnic group knew about the RRLO and even fewer had heard of the RRMT or the "confidential access" procedure. RRLOs therefore investigated only a negligible amount of actual racial incidents, and inmates were also encouraged not to make formal complaints. Complaints were therefore "dealt with" on the wings, resulting in underreporting and underrecording. 
POST PRINT VERSION OF: Ellis, T. (2019). Using Action Research to Improve Race Relations in Prisons. In Oxford Research Encyclopedia of Criminology and Criminal Justice, ed. Henry Pontell. New York and Oxford: Oxford University Press. doi:10.1093/acrefore/9780190264079.013.300

In addition to the previous research studies, there were also important issues that had been identified through the RDS's own internal research.

\section{Recategorization and Parole Eligibility}

There were substantial differences in key factors affecting eligibility for parole between BAME groups identified in Home Office Statistical Bulletin 2/94.6 First, a higher proportion of BAME prisoners had sentences of four or more years. Second, a greater proportion of White offenders had committed burglary or theft offenses, while a greater proportion of Black prisoners had committed robbery offenses. Third, lower proportions of BAME prisoners, compared to White, were recommended for parole, but when "type of offense" and "time to release without parole requirement" were controlled for, these differences were considerably lower.

English prisoners were assessed as they moved through their sentence and, if judged favorably, were recategorized, allowing a move to a lower security prison. Curry (1998) provided an overview of a 100 prisoners who had had contact with NBBPSG groups. The most relevant concern expressed was the impact of being moved around the prison estate on charges against "Good Order and Discipline," which would affect the length of time of required for recategorization. It was important, therefore, to operationalize perceptions of eligibility for recategorization

\section{Asian Prisoners}

Asian prisoners appeared to have consistently fewer problems and complaints than either White or Black prisoners, except for difficulties in practicing their religion, which the majority saw as "ethnic" discrimination. However, the use of the compound "Asian" grouping category masked important differences within it. When Asian ethnicity was broken down further, it was clear that Pakistanis reported a greater number of difficulties. It was therefore important to include a relatively sensitive Asian ethnic classification system].

Once these key concepts from the literature review had been summarized, it was time to reconvene the PSRRG to consider the evidence base and move on to the next stage of the project.

\section{Agreeing on a New Approach}

The discussion of the literature review results at the second meeting of the PSRRG was relatively harmonious with agreement that the types of discrimination identified were consistent with participants' knowledge and experience. The discussion first turned to the fact that both Genders and Player's (1989) and Burnett and Farrell's (1994) studies had been commissioned in response to inspection findings and the subsequent complaints from lobby groups, press coverage, and so on. This then led to a discussion on the extent to which the inspection 7 process might already be contributing to improving race relations in prisons in a pragmatic way. The well-known problems with reliance on inspection reports at that time were then discussed. 
POST PRINT VERSION OF: Ellis, T. (2019). Using Action Research to Improve Race Relations in Prisons. In Oxford Research Encyclopedia of Criminology and Criminal Justice, ed. Henry Pontell. New York and Oxford: Oxford University Press. doi:10.1093/acrefore/9780190264079.013.300

First, despite the amount of official money committed to them, compared to other types of criminal justice research, inspections had no recognized "social science methodology"(Wilcox, 1992, 1993) and were much closer to auditing or monitoring against standards (Clarke, 1999). 8 Second, inspections had been ineffective in ensuring effective responses to problems they had identified. 9

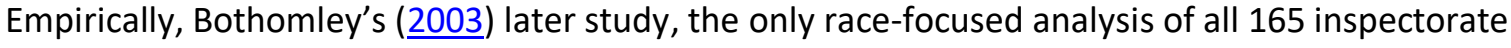
reports on prisons between 1998 and October 2002, showed disappointing results.

- $129(78 \%)$ of reports "mentioned" race, although often in quite limited ways.

- Only $16(10 \%)$ of reports "mentioned" race issues and were subject to "follow-up" reports.

- $15 / 16$ of these reports made recommendations for improvement of race relations (35 recommendations in all).

- Only 11 (31\%) of recommendations were achieved in the follow-up reports.

\section{Beyond Inspections}

It was agreed by all in the PSRRG that inspections would not provide the required approach. Home Office participants also acknowledged that while Genders and Player (1989) and Burnett and Farrell (1994) provided extensive, good-quality studies, they only established a snapshot picture. In discussion this led to an acceptance by all PSRRG parties of the NBBPSG's previous argument that more such studies would be simply a way of "fobbing them off." The NBBPSG argued that "the bottom line is that we are here to negotiate change" In short, members wanted action. While Patton (1997) argued that the evaluation skills of participants can be overlooked, what was crucial at this point was the NBBPSG's acceptance that it did not have a capacity to evidence the impact of any actions but, more importantly, that that capacity was now needed. This involved a discussion of a study that the NBBPSG had referred to that were published by other lobby groups, which it saw as a call for action rather than "research as appeasement." NACRO (2000) had published a relatively small snapshot survey, essentially restating the problem:

The results do not come as a surprise: they confirm other, larger research studies; and they confirm the experience of Nacro staff and many others who have regular contact with prisons around the country.... It is shocking that after 20 years of policy and practice. . . Racist incidents are as commonplace as they ever were and just as rarely reported or acted upon. (p. 48)

Two similar studies were also published during the subsequent research period. The CRE (2003a, 2003b) published a pair of reports in response to the high-profile murder of Zahid Mubarek and inspection findings. While the studies were very detailed, the authors did not offer a clear mechanism, as opposed to general suggestions, for improvement. Edgar and Martin's (2004) study did suggest changes to practice, but these were limited to general changes to the complaints system and relatively aspirational suggestions for tackling institutional racism generally. We were able to use NACRO's (2000) final conclusions as a springboard: "Is the Prison Service confident that it can ... deliver basic human rights? If it cannot, it is time for a radical new approach" (p. 48). 
POST PRINT VERSION OF: Ellis, T. (2019). Using Action Research to Improve Race Relations in Prisons. In Oxford Research Encyclopedia of Criminology and Criminal Justice, ed. Henry Pontell. New York and Oxford: Oxford University Press. doi:10.1093/acrefore/9780190264079.013.300

From an AR perspective, the PSRRG's value was in facilitating all parties' agreement that no approach so far had recognized the need for institutionally specific action or involvement of prisoners, volunteers, and so on or how these would be tied to the management process in a concrete cycle of change.

That helped set the agenda for a radical new approach, which recognized that researchers, policymakers, prisoner lobby groups, and others had so far failed to provide a way of ensuring that problems with race relations in prisons that fulfilled the following criteria:

- systematic monitoring from the prisoners' perspective ;

- establishing baselines from which change could be measured; and

- a requiring prison management, from governors down to frontline officers, to devise a management plan that directly and effectively addressed problems identified by research and whose effectiveness would be continually measured.

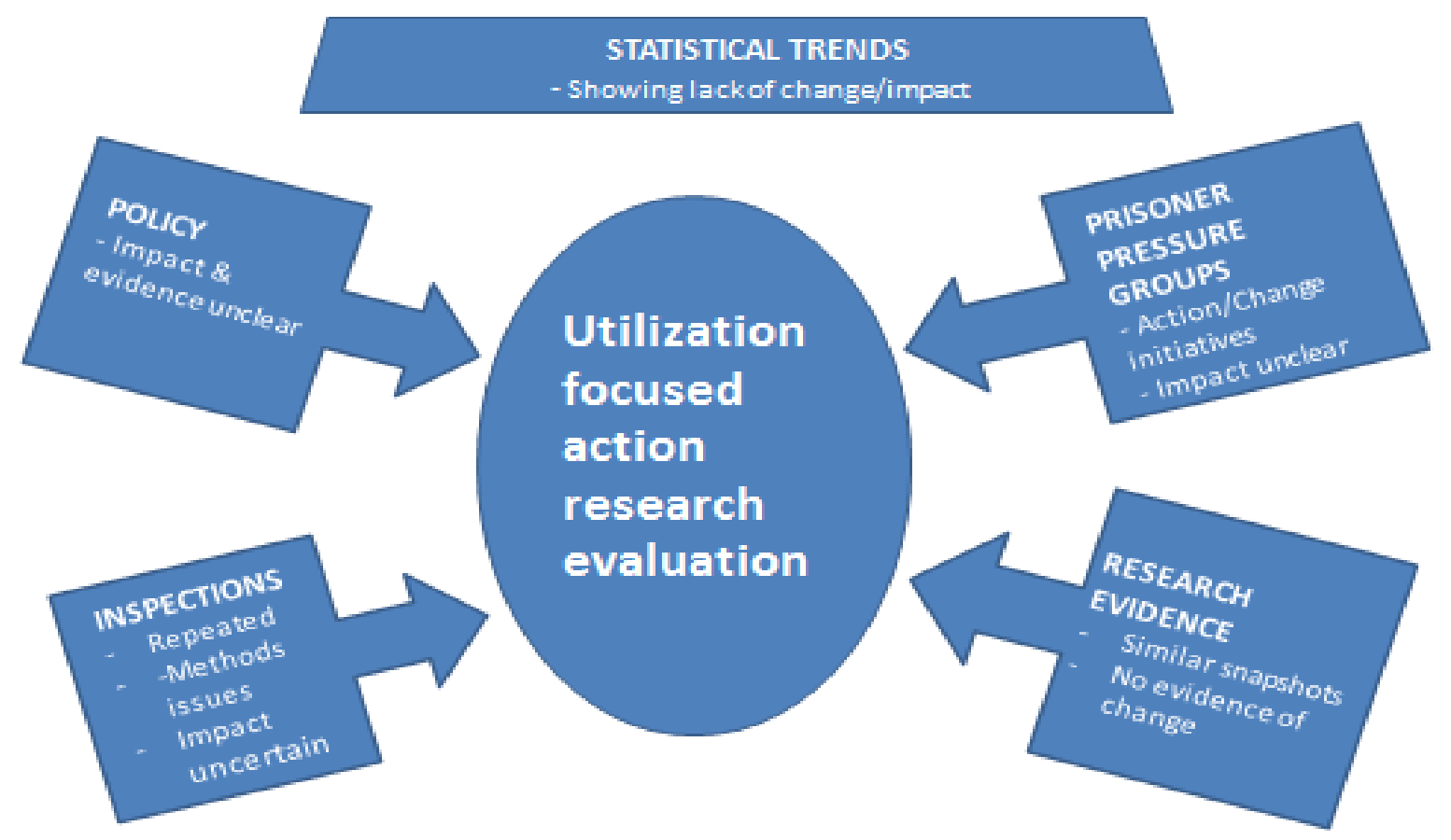

Figure 2: Main factors that resulted in an action research design 
POST PRINT VERSION OF: Ellis, T. (2019). Using Action Research to Improve Race Relations in Prisons. In Oxford Research Encyclopedia of Criminology and Criminal Justice, ed. Henry Pontell. New York and Oxford: Oxford University Press. doi:10.1093/acrefore/9780190264079.013.300

Figure 2 shows the main factors affecting the research design at this stage of the project. This effectively established that the type of policy approach adopted is intimately tied up with the type of research commissioned and the function policy makers attribute to it.

In order to move the project to the next stage, it was important to ensure that NBBPSG members, who felt that had been ignored in the past (see O'Neill 1995), remained equal partners and to avoid the potential for some stakeholders to be suspicious "of the whole idea of evaluation and ... of external evaluator" (Clarke, 1999, p. 29). This now required me to move from my hitherto "internal technical expert" position to one explicitly closer to "involved collaborating participant" (see Mathison, 1994, p. 304) in order to protect the cogenerative element to AR that PSSRG had established and to avoid the two potential key problems at this point:at one extreme, the thendominant view in social science (and criminal justice policymaking) that participants' local knowledge was either invalid or too subjective to transcend bias and/or self-interest; and at the other extreme (potentially from prisoner interest groups), that all local knowledge was valid and uncontaminated (Greenwood \& Levin, 1998, pp. 112-113). Since the PSSRG had effectively overcome the dynamic tension between insider and outsider knowledge, one of my key roles as the trained researcher was, therefore, to maintain effective communication links with all participants, so that cogenerated meanings remained agreed upon and we could move to the next stage of deciding on action options (see Greenwood \& Levin, 1998, pp. 113-114).

My preferred option was based on my familiarity with Greenwood and Levin's (1998, p. 11) explicit adoption of pragmatic AR but also because it was the result of a search for the most appropriate research design to address the research question. However, the researcher is not in a position to insist that participatory action research (PAR) will be used and must let it emerge or risk it being seen as a method of social control rather than empowerment (Greenwood, Whyte, \& Harkavy, 1993). I was aware that Mark and Shotland (1985) had argued that PAR could still be used to "appease the less powerful by giving the appearance of control without relinquishing any actual power" (p. 618) and that it would be relatively easy for the NBBPSG to form this view if promised commitments were not followed through. Indeed, as Rossi and Freeman (1993) put it, this type of evaluation will always be "a political and managerial activity" (p. 15) as well as an application of research methods. As such, I was aiming to develop what Lincoln and Guba (1985) termed a "fourth-generation evaluation" ( $p$. 141): a "socio-political process that is simultaneously diagnostic, change orientated and educative for all the parties involved" so that the evaluator's role was very much one of "negotiator and social change catalyst" Greene (1994, p. 540) and where research skills were only one of a broader set of capacities and experiences required to tackle the pragmatic AR question (Greenwood \& Levin, 1998, p. 11).

\section{Agreeing on an Evaluation Approach and Design}

Elden and Levin (1991) have stressed the importance of "insider" and "outsider" frameworks for PAR, and there was a major readjustment at this point. First, the outcome of the PSRRG meetings was my 
POST PRINT VERSION OF: Ellis, T. (2019). Using Action Research to Improve Race Relations in Prisons. In Oxford Research Encyclopedia of Criminology and Criminal Justice, ed. Henry Pontell. New York and Oxford: Oxford University Press. doi:10.1093/acrefore/9780190264079.013.300

agreed collaboration with single voluntary group, Partners of Prisoners (PoPs, a member of NBBPSG operating in the northwest of England). PoPs provided effective insiders who had networks and firsthand experience of tackling racism in prisons, plus their own views on what should be achieved and potential solutions to problems. At the same time, in 1999, I moved from my outsider Home Office researcher position to become an independent university researcher 'outsider' at the Institute of Criminal Justice Studies (ICJS) , University of Portsmouth, but with full knowledge of the relevant Home Office policy processes. PoPs was unanimously chosen by the PSRRG because it had the infrastructure in place in five prisons in northwest England where it had "tacit agreements" with senior management to make negotiated changes to local race relations policy. There were no complaints about some NBBPSG groups being favored above others, which Mark and Shotland (1985) argue is a major threat to integrity of AR projects.

Importantly, AR's evaluative element was also much more appealing to the NBBPSG than the previous research approaches applied to problems that were already proven to exist. As Stufflebeam and Shinkfield (1985, p. 151) argue, the primary purpose of evaluation is not to prove but to improve. This entails "studying the effectiveness with which existing knowledge is used to inform and guide practical action" (Clarke, $\underline{1999}$, p. 2). AR's evaluative and organizational elements also found favor with the Home Office and Prison Service members of the PSRRG who insisted on the use of social science methods at what Bulmer (1982) described as "the most scientistic conception of applied social research [at] the "hard' end of applied social science" (p. 159).

The main insider/outsider collaboration at this stage was then between me, as the AR researcher, and PoPs who already fulfilled a community activist/quasi research function in the local race and prisons arena. In AR terms, this is a superior approach to that of the then dominant social science research approach, "which chops up reality to make it simpler for the researcher to manipulate and manage" (Greenwood \& Levin, 1998, p. 75). Because theory and action cannot be separated, AR is bound by specific real-life contexts but requires professional researchers to collaborate with participants to find problems of major importance to "local" people and enact solutions to them, which in turn requires systems-informed, pragmatic social science (Greenwood \& Levin, 1998, p. 75).

The AR evaluation design for this project therefore also aimed to incorporate, as far as possible, Patton's (1997) four central tenets of UFE: utility, relevance, practicality, and, crucially, meeting the information needs of decision-makers. Importantly, this involves combining evaluator and stakeholder input and is aimed at providing practical value for both operations and policymaking (Weiss, 1997). The UFE approach allowed us to best address the requirements of the project. It combines AR and a stakeholder-orientated approach to address a practical problem effectively (Clark, 1999, p. 27). It also entails evaluation data being used for diagnostic purposes, informing decisionmaking on changes required, and measuring impact (Clarke, 1999, p. 27). PoPs and I additionally agreed to adopt a "repeated measures" approach (Bryman, 2012) that would establish the first cycle of an AR process that could be repeated any number of times beyond the project time limit. Within this framework, we discussed and agreed on the following aims of the project: 
POST PRINT VERSION OF: Ellis, T. (2019). Using Action Research to Improve Race Relations in Prisons. In Oxford Research Encyclopedia of Criminology and Criminal Justice, ed. Henry Pontell. New York and Oxford: Oxford University Press. doi:10.1093/acrefore/9780190264079.013.300

- To identify the extent to which issues of direct and indirect racism and discrimination were present in each of the prisons.

- To formulate an action plan with prison management and staff to reduce discrimination in areas clearly identified as problematic.

- To negotiate the implementation of targeted interventions with prison management.

- To measure whether these interventions had been effective.

PoPs and I established a clear approach in which joint decision-making was present at all stages of the research process, from identifying the problem and designing research instruments to administering them and interpreting the findings.

\section{Evaluation Design}

This was essentially an exploratory research project and was also intended as a pilot study, since this type of AR has not been applied to this issue before, either in the United Kingdom or elsewhere. It required us to jointly identify the extent of problems in individual prison establishments, PoPs to negotiate appropriate action with prison management, practitioners to take action to address the problems we identified, and evaluators to measure the impact of the actions taken. The intention was that this interactive process could be developed into an approach through which evidencebased policy and practice could be identified locally and rolled out nationally but that would be sensitive to individual establishments' needs. This avoided a generalized appearance of pseudoempowerment (Mark \& Shotland, 1985, p. 618), and PoPs, as advocates of BAME prisoners, had a "real and influential voice in the evaluation process" (Clarke, 1999, p. 29). Further, we also avoided stakeholders being sidelined from having a role in the program itself (Mark \& Shotland, 1985), since they had set up the program in the prisons but did not have the evaluation capacity to measure its impact.

Collaboration between PoPs and myself allowed us play our different frameworks and expertise against each other "to create a new explanatory framework," and we felt that the understanding gained could not have evolved from previously existing frameworks (Elden \& Levin, 1991, p. 132). The unique AR process is summarized in Figure 3. 
POST PRINT VERSION OF: Ellis, T. (2019). Using Action Research to Improve Race Relations in Prisons. In Oxford Research Encyclopedia of Criminology and Criminal Justice, ed. Henry Pontell. New York and Oxford: Oxford University Press. doi:10.1093/acrefore/9780190264079.013.300

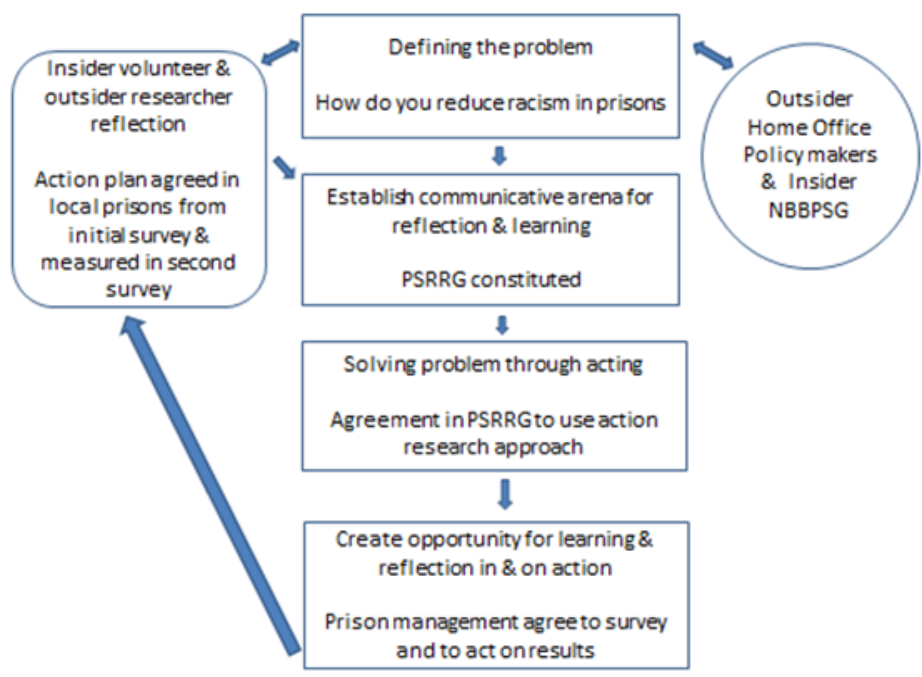

Figure 3. The Cogenerative Action Research Model. Adapted from Greenwood and Levin, (1998, p. 116).

The key elements from the literature review that had been discussed and agreed within the PSRRG were further discussed with PoPs and refined based on their specific experience of dealing with BAME prisoner complaints. These elements were then sufficiently differentiated for use in a questionnaire, using terms for prisoner language and experience. This process effectively ensured that ICJS and PoPs' "worlds of meaning" were combined in an agreed vision of the future evaluation (Fetterman, 1994). The resulting "problem list" used in the questionnaires is outlined in Table 2.

Table 2: The Agreed List of Race Relations Problems To Be Measured

\begin{tabular}{|ll|}
\hline$\bullet$ & Differential treatment of requests and complaints \\
\hline$\bullet$ & Differential treatment through prison discipline \\
\hline - & Access to education and training \\
\hline - & Jood provision \\
\hline - & Accommodation allocation \\
\hline - & Bullied or threatened by Prison Officers \\
\hline - & Re-categorisation \\
\hline - & Bullied/ threatened by prisoners \\
\hline - & Physical abuse by prisoners \\
\hline - & Physical abuse by POs \\
\hline - & Knowledge of RRLOs \\
\hline - & Availability Hair and skin products \\
\hline - & Availability of magazines \& newspapers \\
\hline$\bullet$ & Fair treatment by Prison Officers \\
\hline$\bullet$ & Verbal abuse by prisoners \\
\hline$\bullet$ & Verbal abuse by Prison Officers \\
\hline
\end{tabular}


POST PRINT VERSION OF: Ellis, T. (2019). Using Action Research to Improve Race Relations in Prisons. In Oxford Research Encyclopedia of Criminology and Criminal Justice, ed. Henry Pontell. New York and Oxford: Oxford University Press. doi:10.1093/acrefore/9780190264079.013.300

The resultant operationalized concepts represented a combination of direct (e.g., racist language/insults) and indirect (institutional) discrimination. For this potentially vast area of debate, we relied on a previous Royal Commission, where FitzGerald (1993) had already argued that indirect discrimination was more pervasive and had greater impact on ethnic minority groups than direct discrimination and Reiner (1993) argued that direct racial discrimination was difficult to capture and analyze. We also removed "Asian" as a term and replaced it with the differentiated terms that the prisoners themselves used. Most Asian prisoners self-defined as Pakistani, Bangladeshi, or Indian.

\section{"Doing" the Research}

\section{The Method}

By this point, the evaluation approach was relatively simple. I designed questionnaires based on key concepts in Figure 3 and PoPs administered them locally. My analysis of "before" results was presented in separate reports for each prison with actions suggested. PoPs interpreted this for each prison and then negotiated realistic changes to practice with senior prison managers who were required to formulate them into a management action plan. PoPs then administered the second set of questionnaires after changed practices had been imbedded, and I analyzed them to establish whether there had been any significant change where action had been taken.

In practice, questionnaire construction did require the combining of skills and knowledge of the evaluators and the practitioners. Order and wording of the questionnaire, the administration method, language, literacy, and other problems that PoPs knew would be present all had to be built in and piloted. We also focused on developing a format with clear quantitative, operationalized measures based on changes of policy and practice negotiated with governors. Pilots of selfcompletion versions caused too many difficulties due to the literacy, language, and response issues.

We therefore opted for a structured questionnaire administered as assisted questionnaires (AQs). These ensured a good response rate on small, specific populations, plus they allowed PoPs to note additional qualitative views while assisting. AQs were highly unusual at the time and are still relatively rare in social science research methods. Since that time, however, Holt and Pamment (2011) have noted the beneficial impact of using AQs with young offenders for gathering quantitative data while recognizing risks more associated with interviewing, especially provoking ocially desirable responses (Robson, 2016, pp. 286-287).10

In our case, the standardization of the questionnaire had to be balanced against PoPs staff being able to apply their skill and experience of talking to prisoners (see Robson, 2016, p. 286) to elicit concrete and attitudinal information into a method questionnaire completion. PoPs volunteers were already much more "expert" than the outsider evaluators, and the piloted questionnaires required only minor changes. PoPs staff members were clear that "it was just a slightly more structured way of gaining the information that they always asked about." In practice, PoPs distributed, advised on and collected the questionnaires, ensuring, as far as possible, that all Black and Asian prisoners 
POST PRINT VERSION OF: Ellis, T. (2019). Using Action Research to Improve Race Relations in Prisons. In Oxford Research Encyclopedia of Criminology and Criminal Justice, ed. Henry Pontell. New York and Oxford: Oxford University Press. doi:10.1093/acrefore/9780190264079.013.300

received the questionnaires, working from a list provided by the prisons. Due to PoPs' limited resources, the political context, and the exploratory nature of the pilot project, PoPs restricted their $A Q$ approach to BAME-only prisoners, ruling out a comparison group. Strong views had been expressed against including all prisoners by the NBBPSG in the PSRRG highlighting Rossi and Freeman's $\underline{\underline{1993}}$, p. 15) argument that this type of evaluation always needs to incorporate political and managerial considerations.

\section{Selecting the Prisons}

The original PSRRG discussions envisaged the project taking place in the five prisons in northwest England where POPs were already at different stages of negotiations with the prison managers. However, two prisons (including the only women's prison) were undergoing significant changes in prison management and/or designation and the project was not feasible there. The three prisons that took part in the study were Buckley Hall, Moorlands, and Hindley. As Genders and Player (1989) and Price and Liebling (1998) had found, there were important variations between these establishments. This is also a key element in strengthening the argument for an AR approach, given its locally specific focus. It seemed clear that previous general/national policy aspirations and implementations had foundered in not dealing with these specific local demands to target effective action.

Buckley Hall was a privately run Category C male prison, with a governor who was aware of PoPs' work and who had a good working relationship with staff.11 The management action plan (based on the results of the "before" questionnaire) was formulated jointly between PoPs and the Buckley Hall Race Management Team (RMT) who had a clear commitment to see the project through. The PSRRG had agreed on an ideal six-month period between the first and second questionnaire administration for all prisons in the study, and the RMT felt this would be a reasonable time for action to be formulated and implemented and to see an effect.

Moorlands was a Prison Service-run combined Category $C$ adult male prison and young offender institution. PoPs had a productive, existing working relationship with Moorlands staff but were not able achieve a high level of input into the management action plan, which was formulated by the RMT and implemented without further PoPs involvement. Moorlands management had agreed to an interim review at 6 months but, on the basis of the "before" survey results, was able to adjust this to 12 months (agreed on by the PSRRG), which they felt was a more realistic timeline for the required actions to have an effect.12 Since circumstances in each prison were very different (Genders \& Player, 1989; Price \& Liebling, 1998) the AR allowed for this more flexible approach, which could potentially be used more effectively for routine inspections.

Unfortunately, Hindley presented an insurmountable problem to our agreed AR approach. It was a Remand center when the "before" questionnaires were administered but shortly afterward changed to take only convicted prisoners. Unfortunately this meant the management action plan was no longer relevant to a new population and any "after" results would not be valid. 
POST PRINT VERSION OF: Ellis, T. (2019). Using Action Research to Improve Race Relations in Prisons. In Oxford Research Encyclopedia of Criminology and Criminal Justice, ed. Henry Pontell. New York and Oxford: Oxford University Press. doi:10.1093/acrefore/9780190264079.013.300

\section{Sample Characteristics}

Table 3 shows that, overall, 216 (72\%) prisoners in Buckley Hall and Moorlands returned questionnaires out of a potential population 299 . Over $80 \%$ of all minority ethnic group respondents defined themselves as either Black or Pakistani.13

Table 3 Response Rate \& Sample Characteristics

\begin{tabular}{|l|ll|ll|ll|lc|}
\hline & \multicolumn{2}{|l|}{$\begin{array}{l}\text { 'Before' n } \\
\text { \& response rate }\end{array}$} & \multicolumn{2}{|l|}{$\begin{array}{l}\text { 'After' n } \\
\text { \& response rate }\end{array}$} & $\begin{array}{l}\text { Black prisoners } \\
\%\end{array}$ & \multicolumn{2}{l|}{$\begin{array}{l}\text { Pakistani } \\
\text { Prisoners } \% \\
\text { Before }\end{array}$} & After \\
\hline Buckley Hall & 43 & $(96 \%)$ & 48 & $(89 \%)$ & 69 & 63 & 28 & 19 \\
\hline Moorlands & 77 & $(71 \%)$ & 48 & $(53 \%)$ & 42 & 39 & 42 & 44 \\
\hline Total & $120(78 \%)$ & 96 & $(66 \%)$ & 52 & 51 & 37 & 31 \\
\hline
\end{tabular}

The response rates for Buckley Hall were impressive in both survey periods, while Moorlands was a respectable $71 \%$ in the "before" period but dropped to $53 \%$ in the "after" period. There was no clear explanation for this, but the relative proportions of Black and Pakistani prisoners were similar in both tranches.

\section{Analysis}

As noted, having taken a rather complex route to producing the data, the research design entailed a relatively simple, quantitative analysis of workability. However, a key problem here be might be AR's apparent, but often opaque, rejection of any kind of quantitative element. At times, it seems that Greenwood and Levin $(1998$, p. 77$)$ eschew any type of quantitative measures in an attempt to replace an objective standard of truth with AR's context-bound enquiry. Stringer (2014) also argues:

Numbers . . . are illusory and usually reflect a distorted vision of the research process. . . Numbers by themselves are misleading ... and often oversimplify. ... They also risk reifying certain aspects of a project [and] may focus on tables that quantify relatively trivial features or disregard significant features of the project. (p. 183)

But then the author goes on to argue "Nevertheless, there are occasions when some quantitative information is useful and may be properly included in an evaluative process" (p. 183). This can be confusing for those coming to grips with traditional qualitative/quantitative epistemological paradigms.

It is therefore important to reiterate that while AR's pragmatic philosophy dictates that any outcomes of AR processes must be the result of a collective social judgment and that it questions the conventional (positivist) concept of universal truth due to its discounting of context, it is the application of the AR process, and not the universality of the methods used within the approach, in different contexts, that is paramount (Greenwood \& Levin (1998, p. 79). Essentially, Greenwood and Levin are keen to avoid "socially disengaged, statistically oriented 'disciplines' [that] end up documenting the workings of bureaucratic control structure" (p. 89). But in our case, the use of 
POST PRINT VERSION OF: Ellis, T. (2019). Using Action Research to Improve Race Relations in Prisons. In Oxford Research Encyclopedia of Criminology and Criminal Justice, ed. Henry Pontell. New York and Oxford: Oxford University Press. doi:10.1093/acrefore/9780190264079.013.300

simple, quantitative measures was derived from a long process of discussion, reflection, and agreement between all interested parties, which was therefore seen as part of the scientific method or analytical frameworks that professional action researchers are expected to bring to the AR process (Greenwood \& Levin, 1998, p. 99). These would be part of a wider role of discovering unexpected and counterintuitive explanations and systematically conceptualizing the relationship between what is known about the past and how it relates to possible futures through clear frameworks for action (Greenwood \& Levin, 1998, p. 99). Crucially, our quantitative measures have been used to identify different, context-specific problems, resulting in different actions to address them.

There were also some more prosaic limitations on our quantitative analysis. While a "matched pairs" analysis would have been desirable, the high attrition/turnover within and between prisons dictated an independent samples analysis. We therefore agreed that all questionnaires, in both stages, would be administered to all minority ethnic group prisoners present on a single day to ensure PoPs assistance was assured. Chase-ups (for prisoners who were not initially available) were also carried out by "key prisoners." It was not possible to measure the extent of that approach, and it represents both a strength and a limitation on of the study. The PSRRG agreed early on that that it might be best to adopt the most conservative approach to analysis of any significant change between "before" and "after" questionnaires. For this reason, we adopted a 4-point scale with Likert questions that were divided into binary categories so that we could use a robust, four-cell chi-squared test to measure whether there had been that any identified differences between the two relatively independent "before" and "after" samples. PoPs also kept some records of the negotiations and meetings they had with prisoners, management, and staff, so that the key elements of these could be discussed with the evaluators and matched to the inferences drawn from the analysis of the questionnaire data.

\section{The Findings}

From an AR perspective, since the interventions took place over different time periods and the actions taken were unique in each prison, it is appropriate only to analyze the impact of the project in each individual setting (Genders \& Player, 1989; Price \& Liebling, 1998). The advantage of this style of evaluation is that it can potentially be repeated any number of times if necessary (e.g., where implementation of the action plan was not completed, where action was not successful in reducing discrimination, and/or where the nature of the prison population changes).

The results of the first questionnaires from Buckley Hall showed good race relations. The following key areas of potential discrimination and racism were found to be unproblematic (in that less than $10 \%$ of prisoners identified them as a problem): staff-prisoner or prisoner-prisoner physical and/or verbal abuse, access to education and training, allocation of (wing and/or cell) accommodation, differential treatment of requests and complaints, differential treatment through prison discipline, and availability of magazines and newspapers. The immediate value of the approach to prison 
POST PRINT VERSION OF: Ellis, T. (2019). Using Action Research to Improve Race Relations in Prisons. In Oxford Research Encyclopedia of Criminology and Criminal Justice, ed. Henry Pontell. New York and Oxford: Oxford University Press. doi:10.1093/acrefore/9780190264079.013.300

managers was clear. They, along with PoPs, had formed the impression that there were more difficulties than identified in our questionnaire responses. They accepted that their efforts to improve race relations had therefore been too diffuse to ensure maximum effectiveness. Table 4 shows which issues were identified as the key problem areas in Buckley Hall; whether they were specifically targeted in the action plan, and the extent to which action produced significant, positive changes.

Table 4: Selected action points and analysis of impact at Buckley Hall Prison

\begin{tabular}{|lc|c|c|}
\hline $\begin{array}{l}\text { Issues identified as a problem by \% } \\
\text { respondents }\end{array}$ & $\begin{array}{l}\text { Covered in } \\
\text { action plan }\end{array}$ & Evidence of impact \\
\hline Food provision & $(95)$ & $\checkmark$ & $\checkmark \checkmark(\mathrm{p}=.05)$ \\
\hline Re-categorisation & $(58)$ & $\checkmark$ & $\checkmark \checkmark(\mathrm{p}=.022)$ \\
\hline Knowledge of RRLOs & $(55)$ & $\checkmark$ & $\checkmark$ \\
\hline Hair and skin products & $(41)$ & $\mathbf{X}$ & $\checkmark$ \\
\hline Requests \& complaints & $(40)$ & $\mathbf{X}$ & $\checkmark$ \\
\hline Disciplinary action & $(25)$ & $\mathbf{X}$ & $\checkmark$ \\
\hline Job access & $(47)$ & $\mathbf{X}$ & $\mathbf{X}$ \\
\hline Fair treatment by Prison Officers & $(88)$ & $\mathbf{X}$ & $\mathbf{X}$ \\
\hline
\end{tabular}

Key:

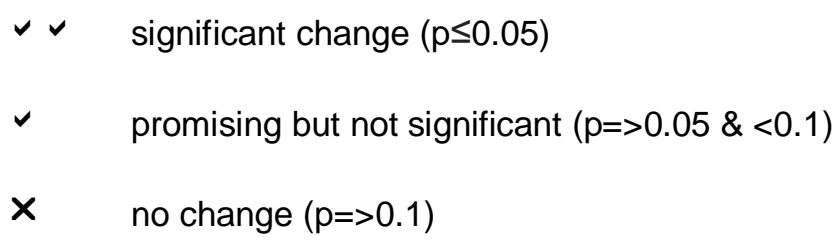

The order of the issues was determined by the level of attention that prison management and PoPs jointly agreed could be devoted to them. Pragmatically, this was a trade-off between the proportion of prisoners identifying the problem, the resources available, and the extent to which a clear plan could be formulated to effect change. RRLOs worked with subgroups of prisoners to jointly agree on additional food items needed in the prison shop, and theme days for a "variety of cultural dishes" were introduced. For recategorization, the core required components were made "open knowledge" so that all prisoners were "aware of what to work towards." It was also made clear that the process would be investigated to check for racial bias. Prison staff were also provided with communications skills training and "ownership and knowledge of Prison Service Order 2800" (Race Relations Policy) was made the "the responsibility of all prison staff, not just the RRLOs." Significant, positive impact was seen in these two areas. The RRLO was given a higher profile and tasked with making themselves better known with BAME prisoners through formal meetings incorporated in prisoner inductions, plus encouragement of continued informal contact. The RRLO also set up monthly meetings with BAME prisoners to raise collective concerns and receive information. This produced positive change just short of significance $(p=0.059)$. While hair and skin products were not 
POST PRINT VERSION OF: Ellis, T. (2019). Using Action Research to Improve Race Relations in Prisons. In Oxford Research Encyclopedia of Criminology and Criminal Justice, ed. Henry Pontell. New York and Oxford: Oxford University Press. doi:10.1093/acrefore/9780190264079.013.300

prioritized in the action plan, PoPs had ascertained during the assisted questionnaire phase that Asian prisoners had the most difficulty with this, while Black prisoners were better catered to. A simple conversation with the prison shop resulted in a change of provision, and the level of satisfaction among Pakistani prisoners rose significantly $(p=0.009)$ from $25 \%$ to $68 \%$.

In Moorlands, fewer areas were found to be unproblematic: differential treatment of requests and complaints, differential treatment through prison discipline, access to education and training, and availability of magazines and newspapers. However, in contrast to Buckley Hall, as Figure 5 shows, BAME prisoners had far worse perceptions of levels of racism than managers or PoPs expected in most other areas.

Table 5: Selected action points and analysis of impact at Moorlands Prison

\begin{tabular}{|lc|c|c|}
\hline Issues identified as a problem by \% respondents & $\begin{array}{c}\text { Covered in } \\
\text { action plan }\end{array}$ & $\begin{array}{c}\text { Evidence of } \\
\text { impact }\end{array}$ \\
\hline Food provision & $(94)$ & $\checkmark$ & $\checkmark \checkmark(\mathrm{p}=.05)$ \\
\hline Job access & $(63)$ & $\checkmark$ & $\checkmark \checkmark(\mathrm{p}=.004)$ \\
\hline Accommodation allocation & $(53)$ & $\checkmark$ & $\checkmark \checkmark(\mathrm{p}=.008)$ \\
\hline Bullied or threatened by Prison Officers & $(34)$ & $\mathbf{X}$ & $\checkmark$ \\
\hline Re-categorisation & $(36)$ & $\mathbf{X}$ & $\checkmark$ \\
\hline Bullied/ threatened by prisoners & $(24)$ & $\mathbf{X}$ & $\checkmark$ \\
\hline Physical abuse by prisoners & $(22)$ & $\mathbf{X}$ & $\checkmark$ \\
\hline Physical abuse by Prison Officers & $(15)$ & $\mathbf{X}$ & $\checkmark$ \\
\hline Knowledge of RRLOs & $(43)$ & $\checkmark$ & $\checkmark$ \\
\hline Hair and skin products & $(32)$ & $\checkmark$ & $\mathbf{X}$ \\
\hline Fair treatment by Prison Officers & $(81)$ & $\mathbf{X}$ & $\mathbf{X}$ \\
\hline Verbal abuse by prisoners & $(43)$ & $\mathbf{X}$ & $\mathbf{X}$ \\
\hline Verbal abuse by Prison Officers & $(38)$ & $\mathbf{X}$ & $\mathbf{X}$ \\
\hline
\end{tabular}

Key:

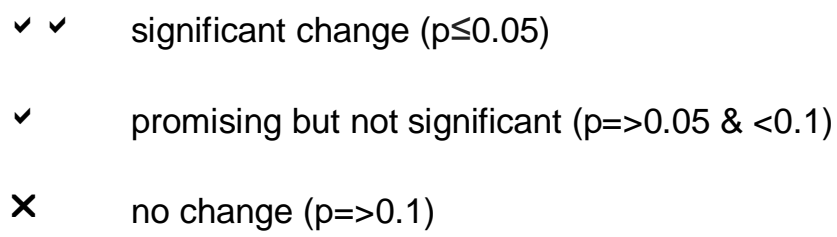

The value of the AR approach was thus demonstrated in a different way. Although PoPs were not directly involved in the management action plan, Moorlands' prison management responded to the action points identified from the evaluation well and, as Table 5 demonstrates, achieved a number of significant improvements. Significantly, the Moorlands management team took the additional step of cross-checking the questionnaire results with their existing data systems (e.g., allocation of accommodation) as suggested by the evaluators but not adopted by the PSRRG on the grounds of being too resource intensive. This type of triangulation represents more effective practice in 
POST PRINT VERSION OF: Ellis, T. (2019). Using Action Research to Improve Race Relations in Prisons. In Oxford Research Encyclopedia of Criminology and Criminal Justice, ed. Henry Pontell. New York and Oxford: Oxford University Press. doi:10.1093/acrefore/9780190264079.013.300

underpinning the translation of evaluation action points into management action plans and subsequent implementation on the ground.

However, this is a double-edged sword. On the positive side, in response to the identified action point, Moorlands made food and other product availability a standing item on the RRMT and race relations subgroup's monthly meetings. Requested changes from BAME prisoners were discussed and action guaranteed within two months. This significantly improved BAME food provision ( $p=$ 0.05 ) but had no impact on hair and skin product availability. For access to jobs, education, and training, the head of regimes was tasked with assessing the internal data on BAME allocation, waiting lists, and refusals. This resulted in a more transparent and overt consideration of this factor, and the "after" results from the questionnaire showed significantly improved $(p=0.004)$ perceptions by BAME prisoners. Based on the action point, the use of internal data identified that there was a higher proportion (ratio 2:1] of young offender prisoners from minority ethnic groups,compared to the adult population. Changes were made so that accommodation statistics provided to RRMT now included finer-grained data (i.e., for individual landings) and BAME data to ensure equal treatment. Again, the "after" results from the questionnaire showed significantly improved $(p=0.008)$ perceptions.

On a more cautionary note, our surveys' identification of problems with perceptions of fairness and physical abuse, threats, and harassment were disputed by the prison managers. This was partly due to our results differing from the official Request and Complaints forms submitted ... [and] because managers argued that all such generated complaints were fully investigated and discussed as a standing item on the RRMT agenda. There is clearly the possibility of underreporting here, but prisoners were reminded of the complaints procedure and were encouraged to use it by PoPs. This did result in an improved response in the "after" survey but not significantly so.

While Hindley was not included in this analysis, the "after" survey was treated as a new "before" survey for a new prisoner population profile. In these circumstances, it is clearly more important for prison managers to identify immediately the different nature of race relations difficulties within any new prisoner population so that the focus of interventions can be altered accordingly. The second Hindley questionnaire clearly identified areas that had not been a problem with the original remand population but were with the newer convicted population: dealing with requests and complaints, equal treatment when considering recategorization, prisoners being bullied by prison officers, and prisoners being bullied by other prisoners. In such cases, the results show a clear need for a new action plan and for the evaluation to be repeated once it has had time to take effect.

\section{Implications of Findings on Improving Race Relations in Prisons}

This pilot study focused on the minority ethnic group population of the two prisons where a full cycle of $A R$ and evaluation was completed. The results suggest that the value and, to some extent, the effectiveness of AR was demonstrated in Buckley Hall and Moorlands. The key targets for race 
POST PRINT VERSION OF: Ellis, T. (2019). Using Action Research to Improve Race Relations in Prisons. In Oxford Research Encyclopedia of Criminology and Criminal Justice, ed. Henry Pontell. New York and Oxford: Oxford University Press. doi:10.1093/acrefore/9780190264079.013.300

relations action established in the management action plans tended to show significantly improved responses and also appeared to encourage improvement in some areas that were not specifically targeted. The mechanism by which this occurred could not be fully established, and, to some extent, involving staff in the planning of those changes made them aware of the purpose of the study. This might be seen either as a problem for project validity in the Hawthorne effect tradition or as the purpose of the AR approach. Perhaps with a fully collaborative approach, the BAME prisoners should have the last word.

The value of this relatively small-scale AR project is in establishing an approach to improving race relations in English prisons that can at least be regarded as more promising than those that went before it. If the circumstances through which the collaboration between policymakers, practitioners, prison management, and evaluators were to recur or be re-established, it would be possible to consider the process we created as a model to be incorporated into the management of more prisons. It might also be considered as an approach to improve the inspection process for race relations, now that new proposed legislation is attempting to strengthen the role and impact of repeated inspections "with provision for inspection reports to trigger action to improve the system from the Secretary of State and governors" (Ministry of Justice, 2016, p. 8). Our approach would help tie inspection recommendations to clear measures of impact. However, in order to achieve this, the approach must be underpinned with backing and support by local prison managers and staff. It would also require a major shift in approach from a single, detailed national policy, an approach still advocated in a 2009 by Spencer, Haselwood-Pócsik, \& Smith, to one where varying agendas would be set by individual prison conditions and changes in them.

Similar arguments have been made for relational audits and relational profiling (see Burnside \& Baker, 1994; Relationships Foundation, 1994) in prisons and the National Health Service, using an audit questionnaire and some in-depth interviewing. Some of the features are similar to our approach. There is a focus on: the specificity of individual establishments, providing benchmarks for measurement of policy and practice, identifying key factors influencing relationships in prisons, and locating weaknesses in relational performance that require attention. However, relational audits lack the participatory and collaborative element, evaluation is based on outsider expertise, and the measures for relational factors are preset as directness, continuity, multiplexity, parity, and commonality.

There is also a clear need to triangulate the questionnaire results with other local prison data and key events when forming the action plan and when administering "after" questionnaires. The extent to which prisoner perceptions vary from objective records suggests an obvious area in which race relations can be improved by effective information dissemination. For example, PoPs were able to establish that, despite the BAME prisoners' perceptions of not being given the same chance of being recategorized as other prisoners, this was not objectively the case. PoPs then ensured that information on the process was disseminated and talked through in a reflective style with minority ethnic group prisoners. The "after" surveys show that this is a key area in which significant 
POST PRINT VERSION OF: Ellis, T. (2019). Using Action Research to Improve Race Relations in Prisons. In Oxford Research Encyclopedia of Criminology and Criminal Justice, ed. Henry Pontell. New York and Oxford: Oxford University Press. doi:10.1093/acrefore/9780190264079.013.300

improvement was made in Buckley Hall. It is also an example of where successful social changes "were encapsulated at the original site [but] would not automatically spread" (Greenwood \& Levin, 1998 , p. 157).

A key advantage of this AR approach is that it can be used dynamically to measure how effective policy initiatives are in reducing discrimination and it can potentially be repeated a number of times where necessary (e.g., where implementation of the action plan was not completed or where action was not successful in reducing discrimination and policy responses have to be reviewed). Another advantage of our approach is that the study was done "double-blind" in the sense that the questionnaires were administered by the voluntary group involved locally as participants and analyzed by an independent evaluator.

Overall, our approach did provide the potential for improving race relations in prisons. In particular, the PAR element provides empowerment through learning (Elden \& Levin, 1991). It did provide all of those involved with new insights and levels of understanding. It also provided opportunity for stakeholders to "learn how to learn" so that they could potentially create new opportunities for action (Clarke, $\underline{1999}$, p. 28).

Unfortunately, the policy and political process cannot guarantee sustained and logical progression on these sort of initiatives. The impact of the Lawrence enquiry14 and the acceptance that the prison service was institutionally and overtly racist (see Narey, 2002, p. 2; Darby, 2003, p.14) were strong at the time of our project. However, even in 1999, the chair of the PSRRG commented that race relations had "slipped down the agenda," and the level of research in the area did not grow.

There was certainly a danger, as Denney (1996) noted, that these types of policy initiatives can be seen as reactive and lead only to a temporary focus on the needs of particular group while ignoring the needs of others. Looked at historically, the approach we used was not incorporated into prison management and practice, and it is difficult to conclude that progress has been made. In 2010, the Prison Service Journal produced a special issue on "Race in Prisons." While much work has continued within the Prison Service and the National Offender Management Service, one has the impression that the continual restatement of the problem and new processes appear more prevalent than any measures of success.

\section{Further Reading}

Bostock, J., \& Freeman, J. (2003). "No limits": Doing participatory action research with young people in Northumberland. Journal of Community \& Applied Social Psychology, 13(6), 464-474.

Bosworth, M., Campbell, D., Demby, B., Ferranti, S. M., \& Santos, M. (2005). Doing prison research: Views from the inside. Qualitative Inquiry, 11(2), 249-264. 
POST PRINT VERSION OF: Ellis, T. (2019). Using Action Research to Improve Race Relations in Prisons. In Oxford Research Encyclopedia of Criminology and Criminal Justice, ed. Henry Pontell. New York and Oxford: Oxford University Press. doi:10.1093/acrefore/9780190264079.013.300

Bryan, K., Freer, J., \& Furlong, C. (2007). Language and communication difficulties in juvenile offenders. International Journal of Language \& Communication Disorders, 42(5), 505-520.

Cahill, C. (2007). Doing research with young people: Participatory research and the rituals of collective work. Children's Geographies, 5(3), 297-312.

Cameron, R. (2009). A sequential mixed model research design: Design, analytical and display issues. International Journal of Multiple Research Approaches, 3(2), 140-152.

Chitsabesan, P., Kroll, L., Bailey, S., Kenning, C., Sneider, S., MacDonald, W., \& Theodosiou, L. (2006). Mental health needs of young offenders in custody and in the community. British Journal of Psychiatry, 188, 534-540.

Edelman, P. B., Holzer, H. J., \& Offner, P. (2006). Reconnecting disadvantaged young men. Washington, DC: Urban Institute Press.

Ellis, T., Pamment, N., \& Lewis, C. (2009). Public protection in youth justice? The Intensive Supervision and Surveillance Programme (ISSP) from the inside. International Journal of Police Science and Management, 11(4), 393-413.

Hartley, S. L., \& MacLean, W. E. Jr. (2006). Reliability and validity of Likert-type scales for people with mental retardation. Journal of Intellectual Disability Research, 50, 813-827.

Heath, S., Brooks, R., Cleaver, E., \& Ireland, E. (2009). Researching young people's lives, London, U.K.: SAGE.

Hingson, R., \& Strunin, L. (1993). Commentary: Validity, reliability, and generalizability in studies of AIDS knowledge, attitudes, and behavioral risks based on subject self-report. American Journal of Preventive Medicine, 9(1), 62-64.

Holstein, J. A., \& Gubrium, J. F. (2003). Inside interviewing: New lenses new concerns. Thousand Oaks, CA: SAGE.

Hurry, J., Brazier, L., \& Wilson, A. (2009). Improving the literacy and numeracy of young offenders. In S. Reder \& J. Bynner (Eds.), Tracking adult literacy and numeracy skills: Findings from longitudinal research (pp. 261-277). Abingdon, U.K.: Routledge.

Miller, G. A. (1956). The magic number seven, plus or minus two: Some limits on capacity for processing information. Psychological Review, 63, 81-97.

Nee, C. (2004). The offender's perspective on crime: Methods and principles in data collection. In A. Needs \& G. Towl (Eds.), Applying psychology to forensic practice (pp. 3-17). London, U.K.: BPS Blackwell. 
POST PRINT VERSION OF: Ellis, T. (2019). Using Action Research to Improve Race Relations in Prisons. In Oxford Research Encyclopedia of Criminology and Criminal Justice, ed. Henry Pontell. New York and Oxford: Oxford University Press. doi:10.1093/acrefore/9780190264079.013.300

Patton, M. Q. (1990). Qualitative evaluation and research methods (2nd ed.). Newbury Park, CA: SAGE.

Plummer, M., Wight, D., Ross, D., Balira, R., Anemona, A., Todd, J., \& Hayes, R. (2004). Asking semiliterate adolescents about sexual behaviour: The validity of Assisted Self-Completion Questionnaire (ASCQ) data in rural Tanzania. Tropical Medicine and International Health, 9, 737-754.

Reason, P., \& Bradbury, H. (Eds.). (2008). The SAGE handbook of action research: Participative inquiry and practice. London, U.K.: SAGE.

Robson, C. (2000). Small-scale evaluation. London, U.K.: SAGE.

Snow, P. C., \& Powell, M. B. (2008). Oral language competence, social skills and high-risk boys: What are juvenile offenders trying to tell us? Children \& Society, 22(1), 16-28.

Tisdall, K., Davis, J., \& Gallagher, M. (2008). Researching with children and young people: Research design, methods and analysis. London, U.K.: SAGE.

Van Laerhoven, H., van der Zaag-Loonen, H. J., \& Derkx, B. H. F. (2004). A comparison of Likert scale and visual analogue scales as response options in children's questionnaires. Acta Paediatrica, 93, 830-835.

Wilson, D. (2006). Some reflections on researching with young Black people and the youth justice system. Youth Justice, 6(3), 181-193.

Youth Justice Board. (2002). The national specification for learning and skills: For young people on a detention and training order in prison service accommodation. London, U.K.: Author.

\section{References}

Ahmad, S. (1996). Fairness in prisons (Doctoral dissertation). University of Cambridge, Cambridge, U.K.

Argyris, C., Putnam, R., \& McClain Smith, D. (1985). Action science: Concepts, methods and skills for research and intervention. San Francisco, CA: Jossey-Bass.

Ben-David, S., Silfen, P., \& Cohen, D. (1996). fearful custodial or fearless personal relations: Prison guards' fear as a factor shaping staff-inmate relation prototype. International Journal of Offender Therapy and Comparative Criminology, 40(2), 94-104. 
POST PRINT VERSION OF: Ellis, T. (2019). Using Action Research to Improve Race Relations in Prisons. In Oxford Research Encyclopedia of Criminology and Criminal Justice, ed. Henry Pontell. New York and Oxford: Oxford University Press. doi:10.1093/acrefore/9780190264079.013.300

Ben-David, S., \& Silfen, P. (1994). In quest of a lost father? Inmates' preferences to staff relation in a psychiatric prison ward. International Journal of Offender Therapy and Comparative Criminology, 38(2), 131-139.

Bothomley, S. (2003). Institutionally racist: Good practice or empty words? An evaluation of prison service policy to achieving racial equality (Unpublished doctoral dissertation). University of Portsmouth, Portsmouth, U.K.

Bottoms, A. E., \& Rose, G. (1998). The importance of staff-prisoner relationships: Results from a study in three male prisons. In D. Price \& A. Liebling (Eds.), Staff-prisoner relationships: A review of the literature (pp. 219-229). Unpublished report submitted to HM Prison Service, London, U.K.

Bowling, B., \& Phillips, C. (2002). Racism, crime and justice. Longman Criminology Series Harlow, U.K.: Pearson Education.

Boyd, J. L. (1976). Race of inmate, race of officer, and disciplinary proceedings at a federal correction institution. FCl Research Reports, 8(1), 1-35.

Bryman, A. (2012). Social research methods (4th ed.). Oxford, U.K.: Oxford University Press.

Buchanan, D., \& Bryman, A. (2007). Contextualizing methods choice in organizational research. Organizational Research Methods, 10(3), 483-501.

Bulmer, M. (1982). The uses of social research: Social investigation in public policy-making. London, U.K.: Allen \& Unwin.

Burnett, R., \& Farrell, G. (1994). Reported and unreported racial incidents in prisons. Occasional Paper No. 14. Oxford, U.K.: University of Oxford Centre for Criminological Research

Cameron, R. (2009). A sequential mixed model research design: Design, analytical and display issues. International Journal of Multiple Research Approaches, 3(2), 140-152.

Camp, S. D., Steiger, T. L., Wright, K. N., Saylor, W. G., \& Gilman, E. (1997). Affirmative action and the "level playing field": comparing perceptions of own and minority job advancement opportunities. Prison Journal, 77(3), 313-334.

Caroll, L. (1974). Hacks, Blacks and cons. London, U.K.: Heath.

Chang, D., \& Zastrow, C. H. (1976). Inmates' and security guards' perceptions of themselves and of each other. A comparative study. International Journal of Criminology and Penology, 1, 89-98.

Cheatwood, A. D. (1974). The staff in correctional settings: An empirical investigation of frying pans and fires. Journal of Research in Crime and Delinquency., 11(2), 173-179. 
POST PRINT VERSION OF: Ellis, T. (2019). Using Action Research to Improve Race Relations in Prisons. In Oxford Research Encyclopedia of Criminology and Criminal Justice, ed. Henry Pontell. New York and Oxford: Oxford University Press. doi:10.1093/acrefore/9780190264079.013.300

Clarke, A. (1999). Evaluation research: An introduction to principles, methods and practice. London, U.K.: SAGE.

Clements, J. (2002) Diversity and Equality: Molding a new future around racial equality. Prison Service News, July/August 2002.

Clemmer, D. (1940). The prison community. New York, NY: Holt, Rinehart \& Winston.

Commission for Racial Equality. (2003a). The murder of Zahid Mubarek: A formal investigation by the Commission for Racial Equality into HM Prison Service of England and Wales, Part 1. London, U.K.: Author.

Commission for Racial Equality (2003b). Racial equality in prisons. A formal investigation by the Commission for Racial Equality into HM Prison Service of England and Wales Part 2. London, U.K.: Author.

Curry, D. (1998). National body of Black prisoner support groups. Race Relations News Letter, 1, 5-6.

Dabiri, E. (2015, May 22). Is it time to ditch the term "Black, Asian and minority ethnic" (BAME)? The Guardian.

Darby, P. (2003) The Way Ahead: PSN talks to Phil Wheatley. Prison Service News (PSN), March, 2003 p.13

Dantzker, M. L., \& Hunter, R. D. (2012). Research Methods For Criminology And Criminal Justice (3rd Edition). Sudbury, MA: Jones and Bartlett Learning.

Denney, D. (1996). Discrimination and anti-discrimination in probation. In T. May \& A. A. Vass (Eds.), Working with offenders: Issues, contexts and outcomes (pp. 51-75). London, U.K.: SAGE.

Edgar, K., \& Martin, C. (2004). Perceptions of race and conflict: Perspectives of minority ethnic prisoners and of prison officers. Home Office Online Report 11/04. London, U.K.: Home Office.

Elden, M., \& Levin, M. (1991). Cogenerative learning: Bringing participation into action research. In W. F. Whyte (Ed.), Participatory action research. Newbury Park, CA: SAGE. 127-142

Ellis, T., Jenkins, C., \& Smith, P. (2015). Evaluation of the introduction of personal issue body worn video cameras (Operation Hyperion) on the Isle of Wight: Final report to Hampshire Constabulary. Portsmouth, U.K.: University of Portsmouth.

Ellis, T., Tedstone, C., \& Curry, D. (2004). Improving race relations in prisons: What works? Home Office Online Report 12/04. London, U.K.: Home Office.

Etzioni, A. (1975). A comparative analysis of complex organisations (2nd ed.). New York, NY: Free Press. 
POST PRINT VERSION OF: Ellis, T. (2019). Using Action Research to Improve Race Relations in Prisons. In Oxford Research Encyclopedia of Criminology and Criminal Justice, ed. Henry Pontell. New York and Oxford: Oxford University Press. doi:10.1093/acrefore/9780190264079.013.300

Fairchild, B. (1995, July). Screening office hires thousands at prison agencies. Insight Into Corrections, pp. 2-8.

Fetterman, D. M. (1994). Empowerment evaluation. Evaluation Practice, 15(1), 1-15.

Flanagan, T. J. (1983). Correlates of institutional misconduct among state prisoners. Criminology, 21, 29-39.

Goffman, E. (1961). On the characteristics of total institutions: Staff-inmate relation. In R. D. Cressey (Ed.), The prison: Studies in institutional organization and change (pp.68-106). New York, NY: Holt, Reinhart \& Winston.

Fox, J. G. (1982). Organizational and racial conflict in maximum-security prisons. NIJ Pub A7713 BO957. Lexington, MA: Lexington Books.

Genders, E., \& Player, E. (1989). Race relations in prison. Oxford, U.K.: Clarendon Press.

Goetting, A. (1985). Racism, sexism, and ageism in the prison community. Federal Probation, 44(3), 10-22.

Goetting, A., \& Howsen, R. M. (1983). Blacks in prison: A profile. Criminal Justice Review, 8(2), 21-31. Greenwood, D. J., Whyte, W. F., \& Harkavy, I. (1993). Participatory action research as a process and as a goal. Human Relations, 46(2), 175-191.

Greenwood, D. J., \& Levin, M. (1998). Introduction to action research. London, U.K.: SAGE.

Greene, J. G. (1994). Qualitative programme evaluation: Practice and promise. In N. K Denzin \& Y. S Lincoln (Eds.), Handbook of qualitative research (pp. 530-554). Thousand Oaks, CA: SAGE.

Guba, E. G., \& Lincoln, Y. S. (1989). Fourth generation evaluation. Newbury Park, CA: SAGE.

Herr, K., \& Anderson, G. L (2005). The action research dissertation: A guide for students and faculty. London, U.K.: SAGE.

HM Prison Service (2002) Prison Service Order 2800 Race Relations. London: HM Prison Service Hochstedler, E. (1982). Analysis of impediments to hiring minorities in criminal justice agencies. Milwaukee: University of Wisconsin.

Holt, A., \& Pamment, N. (2011). Overcoming the challenges of researching "young offenders": Using assisted questionnaires - a research note. International Journal of Social Research Methodology, 14(2), 125-133.

Institute of Race Relations. (n.d.). Definitions. London, U.K.: Author. 
POST PRINT VERSION OF: Ellis, T. (2019). Using Action Research to Improve Race Relations in Prisons. In Oxford Research Encyclopedia of Criminology and Criminal Justice, ed. Henry Pontell. New York and Oxford: Oxford University Press. doi:10.1093/acrefore/9780190264079.013.300

Jackson, J. (1997). Race equality in prisons: The role of the race relations liaison officer. Briefing Paper. London, U.K.: Prison Reform Trust.

James, A. L., Bottomley, A. K., Leibling, A., \& Clare, E. (1997). Privatizing prisons: Rhetoric and reality. London, U.K.: SAGE.

Komiya, N. (1995). A comparative study of racial justice in English and Japanese prisons. International Journal of Comparative and Applied Criminal Justice, 19(2), 269-274.

Lewis, T., \& Ellis, C. (2005). Root and branch review of race and the CJS statistics: Final report. London, U.K.: Home Office.

Lincoln, Y. S., \& Guba, E. G. (1985). Naturalistic inquiry. Newbury Park, CA: SAGE.

Macpherson, W (1999). The Stephen Lawrence inquiry. Report of an inquiry by Sir William Macpherson of Cluny. Advised by Tom Cook, The Right Reverend Dr John Sentamu and Dr Richard Stone. Cm 4262-1. London, U.K.: Home Office.

Maine Department of Corrections. (1987). Affirmative action plan. ME04333 B1910. Augusta: Author. Maine Department of Corrections. (1982). Affirmative action plan. ME04333 A0722. Augusta: Author. Mathison, S. (1994). Rethinking the evaluator role: partnerships between organizations and evaluators. Evaluation and Program Planning, 17(3), 299-304.

McCorkle, L. W., \& Korn, R. (1962). Guard-Inmate Relationships in Prison. In N. Johnston, L. Savitz, \& M. E. Wolfgang (Eds.), The sociology of punishment and corrections. New York, NY: Wiley. 108-110

(24) (PDF) Prison Research From the Inside. Available from:

https://www.researchgate.net/publication/272492868 Prison Research From the Inside [accessed Jan 24 2019].

Morgan, R. (1997). Imprisonment: Current concerns and a brief history since 1945. In M. Maguire, R. Morgan, \& R. Reiner (Eds.), Oxford handbook of criminology (2nd ed.). Oxford, U.K.: Oxford University Press. 1137-1194

Mark, M. M., \& Shotland, R. L. (1985). Stakeholder-based evaluation and value judgements. Evaluation Review, 9(5), 605-626.

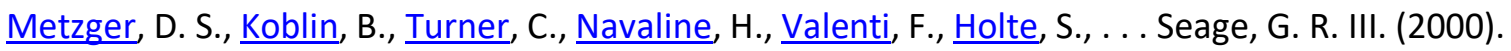
Randomized controlled trial of audio computer-assisted self-interviewing: Utility and acceptability in longitudinal studies. American Journal Epidemiology, 152(2), 99-106.

Ministry of Justice. (2016). Prison safety and reform. Cm 9350. London, U.K.: Author. 
POST PRINT VERSION OF: Ellis, T. (2019). Using Action Research to Improve Race Relations in Prisons. In Oxford Research Encyclopedia of Criminology and Criminal Justice, ed. Henry Pontell. New York and Oxford: Oxford University Press. doi:10.1093/acrefore/9780190264079.013.300

Moskoff, M. R. (1980). A special study of the Wisconsin Council on Criminal Justice. Madison: Research, Evaluation and Policy Section, Wisconsin Council on Criminal Justice.

National Association for the Care and Resettlement of Offenders. (2000). Race and prisons: A snapshot survey. London, U.K.: Author.

Narey, M. (2002). Racism in the prison service. Prison Service Journal, 144, 7-10.

O'Neill, I. T (1995). Implementation frailties of Guba and Lincoln's fourth generation evaluation theory. Studies in Educational Evaluation, 21, 5-21.

Owen, B. A. (1985). Race and gender relations among prison workers. Crime \& Delinquency, 31(1), 147-159.

Patton, M. Q. (1986). Utilization-focused evaluation. Beverly Hills, CA: SAGE.

Patton, M. Q. (1997). Utilization-focused evaluation: The new century text (3rd ed.) Thousand Oaks, CA: SAGE.

Phillips, C., \& Bowling, B. (2002). Racism, ethnicity, crime and criminal justice. In M. Maguire, R. Morgan, \& R. Reiner (Eds.), Oxford handbook of criminology (pp. 602-608). Oxford, U.K.: Oxford University Press.

Petersilia, J. R. (1983). Racial disparities in the criminal justice system. Santa Monica, CA: Rand Corporation.

Petersilia, J. R., Honig, P. K., \& Hubay, C. A. (1980). The prison experience of career criminals. Santa Monica, CA: Rand Corporation.

Plummer, M. L., Wight, D., Ross, D. A., Balira, R., Anemona, A., Todd, J., . . Hayes, R. J. (2004). Asking semi-literate adolescents about sexual behaviour: The validity of assisted self-completion questionnaire (ASCQ) data in rural Tanzania. Tropical Medicine \& International Health, 9(6), 737-754.

Poole, E. D., \& Regioli, R. M. (1980). Race, institutional rule breaking, and disciplinary response: A study of discretionary decision making in prison. Law and Society Review, 14, 931-946.

Price, D., \& Liebling, A. (Eds.). (1998). Staff-prisoner relationships: A review of the literature. Unpublished report submitted to HM Prison Service, London, U.K.

Prison Statistics England and Wales. (1998). Home Office Statistical Bulletin 21/94. London, U.K.: Home Office.

Prison Statistics England and Wales 1997 Cm 4017. London: The Stationery Office 
POST PRINT VERSION OF: Ellis, T. (2019). Using Action Research to Improve Race Relations in Prisons. In Oxford Research Encyclopedia of Criminology and Criminal Justice, ed. Henry Pontell. New York and Oxford: Oxford University Press. doi:10.1093/acrefore/9780190264079.013.300

Ramirez, J. (1983). Race and the apprehension of inmate misconduct. Journal of Criminal Justice, 11(5), 413-427.

Reason, P., \& Bradbury, H. (2008). Introduction. In P. Reason \& H. Bradbury (Eds.), The SAGE handbook of action research: Participative inquiry and practice (pp. 1-10). London, U.K.: SAGE Relationships Foundation. (1996). Relational prison audits: Results of a pilot audit. Belmarsh Prison. Cambridge, U.K.: Author.

Robson, C. (2016). Real world research: A resource for social scientists and practitioner-researchers (4th ed.), Oxford, U.K.: Blackwell.

Rossi, P. H., \& Freeman, H. E. (1993). Evaluation: A systematic approach (5th ed.). Newbury Park, CA: SAGE.

Shapira, R., \& Navon, D. (1985). Staff-inmate co-operation in Israeli Prisons: Towards a nonfunctionalist theory of total institutions. International Review of Modern Sociology, 15, 131-146.

Smartt, U., \& Vagg, J. (1998). Prison works? Contemporary developments in prison labour. Prison Service Journal, 120.

Spencer, J., Haselwood-Pócsik, I. \& Smith, E. (2009) 'Trying to get it right': What prison staff say about implementing race relations policy. Criminology \& Criminal Justice. Vol: 9(2): 187-206 DOI: 10.1177/1748895809102552.

Stufflebeam, D. L., \& Shinkfield, A. J. (1985). Systematic evaluation: A self-instructional guide to theory and practice. Dordrecht, The Netherlands: Kluwer Nijhoff.

Sykes, G. M. (1958). The society of captives. Princeton, NJ: Princeton University Press.

Tonry, M., \& Melewski, M. (2008). The malign effects of drug and crime control policies on Black Americans. Crime and Justice, 37(1), 1-44.

Walsh, N. P. (2001, June 24). Ethnic time bomb in our jails: Criminal justice is racially biased. Observer.

Weiss, C. H. (1997). How can theory-based evaluation make greater headway? Evaluation Review, 21(4), 501-524.

White, R. B. (1980). Prediction of adjustment to prison in a federal correctional population. Journal of Clinical Psychology, 36, 1031-1034.

White, B., Day, C., \& Maher, C. (2007). Self-reported risk behaviour among injecting drug users: Self versus assisted questionnaire completion. AIDS Care: Psychological and Socio-medical Aspects of AIDS/HIV, 19(3). 441-447. 
POST PRINT VERSION OF: Ellis, T. (2019). Using Action Research to Improve Race Relations in Prisons. In Oxford Research Encyclopedia of Criminology and Criminal Justice, ed. Henry Pontell. New York and Oxford: Oxford University Press. doi:10.1093/acrefore/9780190264079.013.300

Whyte, W. F. (1991). Participatory action research. Newbury Park, CA: SAGE.

Wilcox, B. (1993). Inspection, time-constrained evaluation and the production of credible knowledge. In R. G. Burgess (Ed.), Educational research and evaluation: For policy and practice? (pp. 81-101). London, U.K.: Falmer Press.

Wilcox, B (1992). Time-constrained evaluation. London, U.K.: Routledge.

\section{Notes}

1 Such terms have been subject to rapid iteration in England and Wales since this time. BAMEs is the term normally used in the United Kingdom to describe people of non-White descent (see Institute of Race Relations, n.d.) but, as ever, this is contested among those who might be subject to such categories or "labels" (see Dabiri, 2015). The overall term is a simplification of part of the overall 16+1 race categorization system adopted through the U.K. census (see Lewis \& Ellis, 2005).

2 Established in 1998 from various groups of practitioners in the criminal justice field, working directly with BAMEs.

$3 \mathrm{HEUNI}$ is the European regional institute in the United Nations Criminal Justice and Crime Prevention program network. HEUNI functions under the auspices of the Finnish Ministry.

4 We combined Genders and Player's original third and fourth categories listed here.

5 Unlikely to care about staff opinion; resistant/amenable; aggressive/controlled; arouse hostility/be acceptable. 
POST PRINT VERSION OF: Ellis, T. (2019). Using Action Research to Improve Race Relations in Prisons. In Oxford Research Encyclopedia of Criminology and Criminal Justice, ed. Henry Pontell. New York and Oxford: Oxford University Press. doi:10.1093/acrefore/9780190264079.013.300

6 Based on 1990 data.

7 HM Inspectorate of Prisons (HMCIP), established in 1980, carries out both thematic inspections (covering a number of establishments) and routine inspections of individual prisons. The latter forms the bulk of its work and consists of announced and unannounced inspections (both short and full inspections) and follow-up reports.

8 Only since November 2017 has HMCIP been given limited "urgent notification" enforcement powers, which provides links to the improved methodological approach.

9 Indeed, the then Chief Inspector of Prisons, Sir David Ramsbotham, was eloquent to the point of exhaustion in retirement in complaining that his recommendations fell on deaf ears.

10 See also White, Day, and Maher (2007) who found self-completion questionnaires produced better accuracy in reporting of risk behavior than interviewer-administered questionnaires, and Plummer et al. (2004, p. 737), who obtained inconclusive results on whether self-completion questionnaires or face-to-face questionnaires were best with semi-literate populations, which was more comparable with our respondents. Metzger et al. (2000) around the same time as our study found audio computer-assisted self-interviewing produced a clear advantage in validity and reliability in enhancing the quality of behavioral assessments, but this was not a realistic option for our research within prisons.

11 For prisoners who cannot be trusted in open conditions but who are otherwise judged to be unlikely to try to escape.

12 Major variations between Moorlands and Buckley Hall were due to a number of factors (e.g., time required to negotiate access; agree on specific action plans; number of issues in each plan, etc.)

$1389 \%$ in the "before" period, $82 \%$ in the "after" period.

14 The racially motivated murder of Stephen Lawrence, a young Black British man from southeast London on April 22, 1993, had a profound effect on criminal justice responses to racism, police practice, and the law. Convictions occurred 19 years later. The public inquiry that was ordered produced the "Macpherson Report" in 1999 (Macpherson, 1999), which resulted in official acceptance of the metropolitan police as institutionally racist. 